\title{
The Efficacy of Ethaboxam as a Soybean Seed Treatment Toward Phytophthora, Phytopythium, and Pythium in Ohio
}

\author{
Kelsey Scott, ${ }^{1}$ Meredith Eyre, ${ }^{1}$ Dair McDuffee, ${ }^{2}$ and Anne E. Dorrance ${ }^{1, \dagger}$ \\ ${ }^{1}$ Department of Plant Pathology, The Ohio State University, Wooster, OH 44691 \\ ${ }^{2}$ Valent USA LLC, Walnut Creek, CA 94596
}

\begin{abstract}
Phytophthora, Phytopythium, and Pythium species that cause earlyseason seed decay and pre-emergence and post-emergence damping off of soybean are most commonly managed with seed treatments. The phenylamide fungicides metalaxyl and mefenoxam, and ethaboxam are effective toward some but not all species. The primary objective of this study was to evaluate the efficacy of ethaboxam in fungicide mixtures and compare those with other fungicides as seed treatments to protect soybean against Pythium, Phytopythium, and Phytophthora species in both high-disease field environments and laboratory seed plate assays. The second objective was to evaluate these seed treatment mixtures on cultivars that have varying levels and combinations of resistance to these soilborne pathogens. Five of eight envi-

stands, and three had significantly greater yield when ethaboxam was used in the seed treatment mixture compared with treatments containing metalaxyl or mefenoxam alone. Three fungicide formulations significantly reduced disease severity compared with nontreated in the seed plate assay for 17 species. However, the combination of ethaboxam plus metalaxyl in a mixture was more effective than either fungicide alone against some Pythium and Phytopythium species. Overall, our results indicate that the addition of ethaboxam to a fungicide seed treatment is effective in reducing seed rot caused by these pathogens commonly isolated from soybean in Ohio but that these effects can be masked when cultivars with resistance are planted.
\end{abstract} ronments received adequate precipitation in the 14 days after planting for high levels of seedling disease development and treatment evaluations. Three environments had significantly greater
Keywords: disease management, field crops, Glycine max, oilseeds and legumes, oomycetes, seed treatments
Soybean (Glycine max L. Merr.) seedling diseases caused by species of Phytophthora, Phytopythium, and Pythium are a major yield constraint in the United States and Canada (Allen et al. 2017; Bradley 2008; Broders et al. 2007; Jiang et al. 2012; Kirkpatrick et al. 2006; Koenning and Wrather 2010; Marchand et al. 2014; Radmer et al. 2017; Rizvi and Yang 1996; Rojas et al. 2017; Wei et al. 2010; Zitnick-Anderson and Nelson 2015). Reduced stands and plants that survive infection have reduced vigor because of root rot, which contributes to lower yields. Soybean fields may need replanting if stand loss is extensive, further reducing profit for farmers through added input costs and lower yield because of delayed planting. In Ohio, field surveys and subsequent pathogenicity assays have identified species of Phytophthora (Ph.), Pythium (Py., syn. Globosporangium), and Phytopythium (Pp.) that pose a serious risk to soybean (Broders et al. 2007, 2009; Dorrance et al. 2004; Vargas Loyo 2018).

Saturated soils favor infections because these conditions are conducive to the development and reproduction of soilborne pathogens and

${ }^{\dagger}$ Corresponding author: A. E. Dorrance; dorrance.1@osu.edu

Funding: Funding was provided by Valent USA LLC and check-off support from the Ohio Soybean Council. Salaries and research support for this project were provided by state and federal funds appropriated to the Ohio Agricultural Research and Development Center, The Ohio State University, and the National Institute of Food and Agriculture, U.S. Department of Agriculture, Hatch Projects, Development of Disease Management Strategies for Soybean Pathogens in Ohio (OH001303). Additional support was provided by the Ohio State University Center for Applied Plant Sciences as part of the Soybean Resistance Team project.

*The $\boldsymbol{e}$-Xtra logo stands for "electronic extra" and indicates that one supplementary figure and two supplementary tables are published online.

Dair McDuffee is employed by Valent.

Accepted for publication 11 December 2019.

(C) 2020 The American Phytopathological Society may lead to large-scale disease epidemics (Kirkpatrick et al. 2006; Martin and Loper 1999; Schroeder et al. 2013). Soybeans at the seed and seedling stage are the most vulnerable to this disease. Crop rotation is not an effective means to manage Pythium seed and root rot because many Pythium spp. also infect commonly rotated crops such as corn or wheat (Broders et al. 2007; Ingram and Cook 1990). Because of the wide host range of many Pythium spp., cover crops have also been reported to increase the incidence of seedling disease of corn (Acharya et al. 2018). The combination of multiple potential hosts, poorly drained soils, and reduced tillage all promote inoculum buildup in the top $7.5 \mathrm{~cm}$ of soil (Workneh et al. 1998).

During surveys of symptomatic soybeans in Ohio and other regions, more than one species of Pythium was isolated from a single infected seedling, indicating a probable Pythium disease complex (Broders et al. 2007, 2009; Dorrance et al. 2004; Zitnik-Anderson and Nelson 2015). Pythium spp. can also form a seed and seedling complex with other soilborne pathogens such as Phytophthora sojae and Rhizoctonia spp. (Rizvi and Yang 1996). More important is the great diversity of Pythium spp. that have been recovered from individual fields (Broders et al. 2007, 2009; Dorrance et al. 2004; Jiang et al. 2012; Marchand et al. 2014; Radmer et al. 2017; Rojas et al. 2017; Zitnik-Anderson and Nelson 2015), indicating a need for more encompassing management tools for a pathogen complex rather than just focusing on a single species.

Integrated disease management that combines resistant cultivars and fungicide seed treatments is recommended for the management of seedling diseases of soybean (Bradley 2008; Dorrance et al. 2009; Garnica and Giesler 2019; Urrea et al. 2013). Unfortunately, few sources of host resistance to Pythium spp. have been identified in soybean germplasm (Bates et al. 2008; Ellis et al. 2013; Rod et al. 2018; Rosso et al. 2008; Rupe et al. 2011; Scott et al. 2019; Urrea et al. 2017). In addition, very little is known about the levels of resistance toward the individual species of Pythium in soybean cultivars currently planted by farmers. Because of the current limitations of the knowledge of levels of host resistance toward Pythium, Pythium seed and root rot is typically managed with fungicide seed treatments (Bradley 2008; Esker and Conley 2012; Gaspar et al. 2014, 2015, 2017; Munkvold 2009). 
The management of early season infections of soybean by $P h$. sojae has additional challenges. The pathotype diversity of Ph. sojae in the north central region of the United States has increased from a few decades ago as populations have adapted to commonly deployed resistance genes. These resistance genes have become ineffective, resulting in the greater reliance on quantitative resistance (Dorrance et al. 2003, 2009, 2016). However, quantitative resistance toward $P h$. sojae is not effective until the plant is at least in the V1 growth stage (when the seedling has one set of trifoliate leaves) (Dorrance and McClure 2001). These challenges have also led to fungicide seed treatments having greater role in the management of Ph. sojae (Anderson and Buzzell 1982; Bradley 2008; Dorrance and McClure 2001; Dorrance et al. 2009).

Fungicide seed treatments are a valuable means of managing early season diseases. The phenylamides (metalaxyl and its active isomer mefenoxam) have been reliable active ingredients in reducing losses in soybean because of early season stand reductions, thereby preserving yield (Anderson and Buzzell 1982; Bradley 2008; Bradley et al. 2001; Dorrance and McClure 2001; Gaspar et al. 2015; Guy et al. 1989; Lueschen et al. 1991; Radmer et al. 2017), even under reduced tillage production systems (Guy and Oplinger 1989). These active ingredients inhibit ribosomal RNA synthesis in oomycetes (Davidse et al. 1983; Randall et al. 2014). In Ohio and across the United States, isolates of several different species of Pythium that are insensitive to metalaxyl and mefenoxam have been recovered from corn and soybean (Broders et al. 2007; Dorrance et al. 2004; Taylor et al. 2002; Radmer et al. 2017). Quinone outside inhibitor (QoI) fungicides have also been used to manage some soybean seed and seedling diseases caused by oomycetes (Bradley 2008; Broders et al. 2007; Matthiesen et al. 2016; Radmer et al. 2017). The efficacy of individual QoI and phenylamide fungicides toward different Pythium species varies. Similar to phenylamide fungicides, the QoI fungicides are also at high risk for the development of resistance in the pathogen population (Broders et al. 2007; Gisi et al. 2002; Radmer et al. 2017). To maintain the ability to manage these seedling diseases and prevent poor stands, replanting, and potential yield loss, new fungicide chemistries should be evaluated for efficacy toward the complex of water molds that cause seed rot and seedling damping off.

Ethaboxam is effective in managing several foliar diseases on pepper and potato caused by different oomycete species, including Phytophthora infestans (Kim et al. 1999, 2004). The mode of action of ethaboxam is the disruption of microtubulin assembly, as modeled in $P h$. infestans (Uchida et al. 2005). Ethaboxam is considered as having low to medium risk for the development of fungicide resistance (Kim et al. 2004). In our earlier studies, ethaboxam was effective against most but not all evaluated species of Pythium (Dorrance et al. 2012). Radmer et al. (2017) reported that 5 of 7 species of Pythium had significant reductions in growth at both 5 and $100 \mathrm{ppm}$ of ethaboxam. Matthiesen et al. (2016) compared the growth of four species of Pythium on ethaboxam amended agar plates, and although it was effective in limiting mycelial growth, the $\mathrm{EC}_{50}$ values were different at 13,18 , and $23^{\circ} \mathrm{C}$. The $\mathrm{EC}_{50}$ value for ethaboxam was lower at 13 compared with $23^{\circ} \mathrm{C}$ for Pythium sylvaticum and higher at 23 compared with $13^{\circ} \mathrm{C}$ for Pythium torulosum. In another study, the combination of ethaboxam and metalaxyl protected soybean seedlings from infections of Py. sylvaticum that were enhanced by cold stress (Serrano et al. 2018). More importantly, White et al. (2019) recently reported an improvement in stand and yield of wheat when the seed treatment included ethaboxam, compared with metalaxyl alone.

Together, these studies suggest that ethaboxam may be a good candidate for effective management of seed and root disease caused by Phytophthora, Phytopythium, and Pythium species in the highdisease environments that occur annually in Ohio. The objectives of our study were to evaluate ethaboxam and metalaxyl alone or in combination in seed treatment mixtures, compare these mixtures with other seed treatments on cultivars with various levels and combinations of resistance to these pathogens in high-disease environments, and evaluate the efficacy of these mixtures in laboratory seed plate assays to isolates representing the breadth and diversity of pathogens that cause soybean seed and seedling diseases in Ohio. This work expands on earlier studies of this fungicide from amended agar and greenhouse assays (Dorrance et al. 2012). Preliminary reports of these studies were published previously (Dorrance et al. 2012; Scott et al. 2016).

\section{Materials and Methods}

Environments. In 2014, 2015, and 2016, eight field sites were selected to study the effects of fungicide seed treatments on early (soybean growth stages V1 and V3) plant populations, final (R8) plant populations, and yield (Table 1). In this study, an "environment" refers to a single field site within a growing season (e.g., VW-2016 is the Van Wert field in 2016). These environments were selected based on a history of soybean seedling disease, high incidence of damping off, and poor drainage caused by soil type. Soil types for the fields were Paulding clay, Latty silty clay, Hoytville clay, and a Ravenna silt loam in Defiance (DEF-2015, DEF-2016), Van Wert (VW-2014, VW-2016), Wood (NWARS-2014, NWARS-2015, NWARS-2016), and Wayne (SNY-2016) counties in Ohio, respectively. One field site was planted each year (for a total of three environments) at the Ohio Agricultural Research and Development Center Northwest Agricultural Research Station (NWARS-2014, NWARS -2015, NWARS-2016). Each year, the field at NWARS was irrigated with 4.1 to $7.4 \mathrm{~cm}$ of water for 2 to 3 days after planting (dap) to ensure saturated soil conditions for optimal disease development (Table 1). The other environments did not have irrigation and were dependent on natural rainfall to produce an environment conducive for oomycete seedling disease.

Field experiments. The seed for each trial was treated at Valent USA LLC's Seed Protection Lab, in Leland, Mississippi. Additional fungicides (ipconazole, fludioxonil, prothioconazole, fluxapyroxad, or pyraclostrobin) and an insecticide (clothianidin, thiamethoxam, imidacloprid, or penflufen) were included in the base mix each year to eliminate any secondary effects from injury caused by insects or seed and seedling damping off caused by fungal pathogens (Fusarium spp., Phomopsis).

The effects of seven different fungicide seed treatments and a nontreated control were evaluated for the effects on stand and yield with the cultivars Conrad and Sloan in 2014 (Table 2). These seven fungicide seed treatment mixtures included metalaxyl or mefenoxam

Table 1. Environment (location-year), planting and harvest dates, number of cultivars, and number of seed treatment formulations evaluated in Ohio in 2014, 2015, and 2016 for efficacy toward seed and seedling diseases of soybean caused by species of Phytophthora, Phytopythium, and Pythium

\begin{tabular}{lcccc}
\hline Environment & Planting date & Harvest date & Number of cultivars & $\begin{array}{c}\text { Number of seed } \\
\text { treatment formulations }\end{array}$ \\
\hline VW-2014 & 26 May & 13 Oct & 2 & 7 \\
NWARS-2014 & 3 Jun & 24 Oct & 2 & 7 \\
NWARS-2015 & 22 Jun & 20 Oct & 3 & 3 \\
DEF-2015 & 26 May & 27 Sep & 4 & 3 \\
NWARS-2016 & 1 Jun & 17,18 Oct & 7 & 2 \\
SNY-2016 & 20 May & 6 Oct & 7 & 2 \\
VW-2016 & 25 May & 8 Oct & 7 & 2 \\
DEF-2016 & 26 May & 15 Oct & 7 & 2 \\
\hline
\end{tabular}

\footnotetext{
${ }^{\mathrm{z}}$ Seed treatment formulations are listed in Table 2 and were provided by Valent USA; seed was treated at Valent USA research station in Leland, Mississippi.
} 
alone at different rates and in combination with ethaboxam in different seed treatment mixtures. Conrad and Sloan have relatively low amounts of partial resistance to Pythium spp. and no Rps genes for Ph. sojae.

In 2015 the efficacy of ethaboxam plus metalaxyl in a seed treatment mixture (Table 2) was compared with those with mefenoxam, as well as pyraclostrobin plus metalaxyl with four cultivars (Conrad, Sloan, Kottman, and Lorain) with various levels and combinations of resistance toward Pythium and Ph. sojae. Kottman has resistance genes Rps $1 k$ and Rps3a (Dorrance et al. 2009), Lorain has resistance gene Rps $1 c$ to $P h$. sojae, and both of these cultivars have moderately high levels of partial resistance to Pythium ultimum var. ultimum, Pythium ultimum var. sporangiiferum, and Pythium irregulare (Balk 2014; Dorrance Lab, unpublished data).

In 2016, one seed treatment formulation containing ethaboxam, metalaxyl plus ipconazole, and the insecticide clothianidin (Table 2) was compared with nontreated seed with seven cultivars for early and late plant populations and yield. The cultivars were Clermont, Dennison, Kottman, Streeter, Conrad, Lorain, and Sloan; these cultivars were selected because each had different levels and combinations of resistance toward Ph. sojae and Pythium spp. (Supplementary Table S1).

Experimental design. Each field experiment (environment) was planted as randomized split plot design with the cultivar as the whole plot and the seed treatments as the subplots with four to eight replicates, depending on the space available in each field. Plots in VW2014 and DEF-2015 were four rows spaced $76.2 \mathrm{~cm}$ apart and 9.1 meters long and a seeding rate of eight seeds per $30.5 \mathrm{~cm}$. Data for stand were collected by counting all soybean plants in the full length of the second row and converted to plants per hectare for analyses. The remaining plots were all planted with four-row cone planters with $38.1 \mathrm{~cm}$ row spacing and a minimum of $7.6 \mathrm{~m}$ in length. The seeding rate was 4.1 seeds per $30.5 \mathrm{~cm}$. Data for stand were collected by counting the soybean plants in $0.9 \mathrm{~m}$ of all four rows in one location of the plot and converted to plants per hectare before analysis. Data for plant populations were collected three times in each growing season, based on soybean developmental growth stages: one or two trifoliate leaves (growth stage V1 to V2), three or four trifoliate leaves (growth stage V3 to V4), and when pods were brown or tan (growth stage R7 to R8). Stand counts were converted into the number of plants per hectare before analysis.

Yield data were collected with plot combines, which also collected weights and moisture readings. Fields at NWARS (-2014, -2015, -2016) were harvested with a Kincaid 8-XP (Kincaid Equipment Manufacturing, Haven, KS) paired with a High Capacity Grain Gage weigh system. (Juniper Systems, Logan, UT). The fields at DEF
(-2015, -2016) and VW (-2014, -2016) were harvested by Tech Services, Inc. (Bluffton, IN) with a combine paired with an Almaco LRX electronic data system. (ALMACO, Nevada, Iowa). The study at SNY-2016 was harvested with an Almaco Specialized Plot Combine (Almaco SPC20) (Almaco, Nevada, IA) equipped with a Harvestmaster Grain Gage system. The yield data for all locations were standardized to $13.5 \%$ moisture and converted to kilograms per hectare.

Field data analyses. The data collected from the field experiments were individually analyzed with a generalized linear mixed model (PROC GLIMMIX) and the Kenward-Roger method for calculating denominator degrees of freedom (Littell et al. 2006). Fungicides and cultivars were fixed, whereas block and block-by-cultivar were random effects. Least square mean comparisons were used to separate the treatments in SAS version 9.4.

The 2016 field data were analyzed across the four environments in order to test for significance of the environment, cultivar, seed treatment, and each of the corresponding interactions on stand and yield. For this analysis, the fixed effects were environment, cultivar, seed treatment, and their interactions, and block and cultivar-by-block nested within environment were random effects.

The seed treatment mixture of metalaxyl $(3.2 \mu \mathrm{g}$ of active ingredient [a.i.]/seed) plus ethaboxam (12.0 $\mu \mathrm{g}$ of a.i./seed) plus clothianidin (75.1 $\mu \mathrm{g}$ of a.i./seed) plus ipconazole (3.8 $\mu \mathrm{g}$ a.i./seed) was compared with the nontreated with environment, cultivar, and seed treatments and their interactions as fixed effects, and block and cultivar by block nested within environment were random effects in PROC GLIMMIX in SAS.

Species identification. All isolates of Phytophthora, Phytopythium, and Pythium used in these experiments (Table 3 ) originated from Ohio soybean fields and were recovered from symptomatic seedlings or from soil baiting. Each isolate was identified to the species level based on morphological characteristics from cultures grown on potato carrot agar plates or from grass blade cultures with a monographic key for the genus Pythium (van der Plaats-Niterink 1981; Waterhouse 1967), as well as sequence analysis of the entire internal transcribed spacer (ITS) region of the ribosomal RNA (White et al. 1990). Each isolate was grown on vegetable juice broth at ambient temperature for 2 to 6 days, and the mycelia was collected on filter paper placed in a Buchner funnel, transferred to a mortar, frozen with liquid nitrogen, ground into a powder, and stored at $-20^{\circ} \mathrm{C}$. DNA was extracted from the mycelia powder as described by ZelayaMolina et al. (2011). Full length of the ITS1-5.8S-ITS4 region was amplified with ITS1 (5'-TCCGTAGGTGAACCTGCGG) and ITS4 (5'-TCCTCCGCTTATTGATATGC) primers (White et al. 1990). The PCR master mix was adapted from the Promega Protocol (Promega Corp, Madison, WI, US), which consisted of $5.0 \mu$ l of GoTaq

Table 2. Fungicide seed treatments evaluated for efficacy toward seed and seedling diseases of soybean caused by Phytophthora sojae, Phytopythium spp., and Pythium spp. in field studies in Ohio

\begin{tabular}{|c|c|c|}
\hline Environment & Active ingredient and rate ( $\mu \mathrm{g}$ of a.i./seed) & Trade name \\
\hline NWARS-2014, VW-2014 & $\begin{array}{l}\text { Metalaxyl }(6.2)+\text { clothianidin }(75.1)+ \\
\text { ipconazole }(3.8)\end{array}$ & $\begin{array}{l}\text { Inovate Pro ( } 2.47 \mathrm{lb} \text { of a.i./gal) + Sebring ( } 2.65 \mathrm{lb} \text { if } \\
\text { a.i./gal) }\end{array}$ \\
\hline $\begin{array}{l}\text { NWARS-2014, 2016; VW-2014, 2016; } \\
\text { SNY-2016; DEF-2016 }\end{array}$ & $\begin{array}{l}\text { Metalaxyl }(3.2)+\text { ethaboxam }(12.0)+ \\
\text { clothianidin }(75.1)+\text { ipconazole }(3.8)\end{array}$ & $\begin{array}{l}\text { Inovate Pro ( } 2.47 \mathrm{lb} \text { of a.i./gal) + Intego Solo ( } 3.2 \mathrm{lb} \\
\text { of a.i./gal) }\end{array}$ \\
\hline NWARS-2014, VW-2014 & $\begin{array}{l}\text { Metalaxyl }(6.2)+\text { ethaboxam }(12.0)+ \\
\text { clothianidin }(75.1)+\text { ipconazole }(3.8)\end{array}$ & $\begin{array}{l}\text { Inovate Pro }(2.47 \mathrm{lb} \text { of a.i./gal })+\text { Sebring }(2.65 \mathrm{lb} \\
\text { of a.i./gal })+ \text { Intego Solo }(3.2 \mathrm{lb} \text { of a.i./gal })\end{array}$ \\
\hline NWARS-2014, VW-2014 & $\begin{array}{l}\text { Mefenoxam (11.7) + thiamethoxam (77.8) + } \\
\text { fludioxonil (3.8) }\end{array}$ & CruiserMaxx Plus (2.47 lb of a.i./gal) \\
\hline NWARS-2014, VW-2014 & $\begin{array}{l}\text { Mefenoxam }(23.0)+\text { thiamethoxam }(77.8)+ \\
\text { fludioxonil (3.8) }\end{array}$ & $\begin{array}{l}\text { CruiserMaxx Plus ( } 2.47 \mathrm{lb} \text { of a.i./gal) + Apron XL ( } 3.0 \\
\text { lb of a.i./gal) }\end{array}$ \\
\hline NWARS-2014, VW-2014 & $\begin{array}{l}\text { Metalaxyl }(24.9)+\text { prothioconazole }(8.1)+ \\
\text { penflufen }(4.0)+\text { imidacloprid }(101.0)\end{array}$ & $\begin{array}{l}\text { Evergol Energy }(1.47 \mathrm{lb} \text { of a.i./gal })+\text { Allegiance-FL } \\
(2.65 \mathrm{lb} \text { of a.i./gal })+\text { Gaucho }(5 \mathrm{lb} \text { of a.i./gal })\end{array}$ \\
\hline NWARS-2014, 2015; VW-2014; DEF-2015 & $\begin{array}{l}\text { Metalaxyl }(13.2)+\text { pyraclostrobin }(16.9)+ \\
\text { fluxapyroxad }(8.3)+\text { imidacloprid }(127.0)\end{array}$ & $\begin{array}{r}\text { Acceleron package: Acceleron DX } 109(0.8 \mathrm{fl} \mathrm{oz} / \mathrm{cwt})+ \\
\text { Acceleron DX } 309(0.4 \mathrm{fl} \mathrm{oz} / \mathrm{cwt})+\text { Acceleron DX } 612 \\
(0.240 \mathrm{fl} \mathrm{oz} / \mathrm{cwt})+\text { Acceleron IX } 409(2.00 \mathrm{fl} \mathrm{oz} / \mathrm{cwt})\end{array}$ \\
\hline NWARS-2015, DEF-2015 & $\begin{array}{l}\text { Metalaxyl }(3.2)+\text { ethaboxam }(12.0)+ \\
\text { ipconazole }(4.0)+\text { clothianidin }(81.0)\end{array}$ & Intego Suite (3.37 fl oz/cwt) \\
\hline NWARS-2015, DEF-2015 & $\begin{array}{l}\text { Mefenoxam }(11.7)+\text { fludioxonil }(3.8)+ \\
\text { thiamethoxam }(77.9)\end{array}$ & CruiserMaxx Advanced (3.2 fl oz/cwt) \\
\hline
\end{tabular}


Flexi, $1.5 \mu \mathrm{l}$ of $25 \mathrm{mM} \mathrm{MgCl}_{2}, 1.0 \mu \mathrm{l}$ containing $2.5 \mathrm{mM}$ each $\mathrm{dNTP}, 0.25 \mu \mathrm{l}$ GoTaqFlexi DNA polymerase, $1.0 \mu \mathrm{l}$ of $10 \mu \mathrm{M}$ of ITS1 primer, $1.0 \mu \mathrm{l}$ of $10 \mu \mathrm{M}$ of ITS4 primer, $1 \mu \mathrm{l}$ of DNA template $(50 \mathrm{ng} / \mu \mathrm{l}$ ), and $12.25 \mu \mathrm{l}$ of ultrapure distilled water (Invitrogen, Carlsbad, CA, US). The PCR conditions were $95^{\circ} \mathrm{C}$ for $5 \mathrm{~min}$, followed by 30 cycles: denaturation at $94^{\circ} \mathrm{C}$ for $1 \mathrm{~min}$; primer annealing at $53^{\circ} \mathrm{C}$ for $1 \mathrm{~min}$, and extension at $72^{\circ} \mathrm{C}$ for $1 \mathrm{~min}$. PCR products were cleaned with a ExoSAP-IT (Affymetrix Inc, Ohio, USA) kit (exonuclease I and shrimp alkaline phosphate), and DNA quality was evaluated on $1 \%$ agarose gel. Cleaned amplicons were submitted for sequencing at the Ohio Agricultural Research and Development Center Molecular and Cellular Imaging Center in Wooster, Ohio.

Table 3. Isolates of Phytophthora, Phytopythium, and Pythium, survey years, and county in Ohio where they originated, used in a seed plate assays to evaluate the efficacy of three fungicide seed treatments and determine the relative aggressiveness of each isolate

\begin{tabular}{|c|c|c|c|}
\hline Watermold & Isolate code & Year & County \\
\hline \multirow[t]{4}{*}{ Pythium attrantheridium } & $\mathrm{MDa} 4.2 \mathrm{~b}$ & 2015 & Defiance \\
\hline & MVa12.5b & 2015 & Van Wert \\
\hline & 17SNY111.3- & 2017 & Snyder \\
\hline & $17 \mathrm{CLN} 214.4 \mathrm{~A}^{\mathrm{z}}$ & 2017 & Clinton \\
\hline \multirow[t]{2}{*}{ Pythium cryptoirregulare } & Erie 2-6-4 & $2006 / 2007$ & Erie \\
\hline & Craw 1-1-10 & $2006 / 2007$ & Crawford \\
\hline Pythium diclinum & MVa3.5b & 2015 & Van Wert \\
\hline \multirow[t]{4}{*}{ Pythium dissotocum } & MDa2.1a & 2015 & Defiance \\
\hline & D411.1 & 2016 & Defiance \\
\hline & N405.1 & 2016 & Wood \\
\hline & MVa23.5az & 2015 & Van Wert \\
\hline \multirow[t]{2}{*}{ Pythium heterothallicum } & MDa6.5b & 2015 & Defiance \\
\hline & $\mathrm{N} 405.4^{\mathrm{z}}$ & 2016 & Wood \\
\hline \multirow[t]{4}{*}{ Pythium inflatum } & MDa11.2a & 2015 & Defiance \\
\hline & MVa3.3a & 2015 & Van Wert \\
\hline & MVa5.3a & 2015 & Van Wert \\
\hline & D206. $1^{\mathrm{z}}$ & 2016 & Defiance \\
\hline \multirow[t]{3}{*}{ Pythium irregulare } & Mont 1-4-7 & $2006 / 2007$ & Montgomery \\
\hline & Sand 1-6-22 & $2006 / 2007$ & Sandusky \\
\hline & Wood 1-6-9 & $2006 / 2007$ & Wood \\
\hline \multirow[t]{2}{*}{ Pythium lutarium } & MVa20.4b & 2015 & Van Wert \\
\hline & MVa23.5b & 2015 & Van Wert \\
\hline Pythium nodosum & MWa9.1a1 & 2015 & Franklin \\
\hline \multirow[t]{3}{*}{ Pythium oopapillum } & $\mathrm{MDa} 2.4 \mathrm{~b}$ & 2015 & Defiance \\
\hline & MVa1.4a & 2015 & Van Wert \\
\hline & N110.1 & 2016 & Wood \\
\hline Pythium pleroticum & MVa13.3b & 2015 & Van Wert \\
\hline \multirow[t]{3}{*}{ Pythium torulosum } & $\mathrm{MDa} 4.4 \mathrm{~b}$ & 2015 & Defiance \\
\hline & MVa7.2a & 2015 & Van Wert \\
\hline & $\mathrm{N} 205.1^{\mathrm{z}}$ & 2016 & Wood \\
\hline \multirow{6}{*}{$\begin{array}{l}\text { Pythium ultimum var. } \\
\text { ultimum }\end{array}$} & MDa5.2b & 2015 & Defiance \\
\hline & Miami137 & $2006 / 2007$ & Miami \\
\hline & MVa1.2a & 2015 & Van Wert \\
\hline & MVa21.4b & 2015 & Van Wert \\
\hline & N508.1 & 2016 & Wood \\
\hline & $\mathrm{N} 201.2(2)$ & 2016 & Wood \\
\hline \multirow[t]{4}{*}{ Phytophthora sansomeana } & $\mathrm{MVa} 2.5 \mathrm{~b}$ & 2015 & Van Wert \\
\hline & MVa8.4b & 2015 & Van Wert \\
\hline & 17SNY208.5- & 2017 & Wayne \\
\hline & 17CLN111.2 & 2017 & Clinton \\
\hline \multirow[t]{2}{*}{ Phytophthora sojae } & OH.12108.06.03 & 2012 & Van Wert \\
\hline & R25_1-97-01 & & Standard isolate \\
\hline \multirow[t]{2}{*}{ Phytopythium helicoides } & MVa14.4b & 2015 & Van Wert \\
\hline & D502.1 & 2016 & Defiance \\
\hline Phytopythium litorale & D206.3 & 2016 & Defiance \\
\hline Phytopythium mercuriale & N109.1(2) & 2016 & Wood \\
\hline \multirow[t]{3}{*}{ Phytopythium vexans } & MWa12.1a & 2015 & Wood \\
\hline & 17SNY101.1+ & 2017 & Wayne \\
\hline & 17CLN111.1 & 2017 & Clinton \\
\hline
\end{tabular}

$\overline{\mathrm{z}}$ Isolate did not cause measurable seed rot in the seed plate assay and was excluded from the final analyses.
Sequence was trimmed with CodonCode Aligner and then blasted against the sequences in the NCBI database. Sequence identities of $99 \%$ to validated cultures were considered a match for species identification.

Laboratory seed plate assay. Commercial formulations of three seed treatment mixtures were compared with nontreated seed in a labbased seed plate assay. The seed treatments were: (i) ethaboxam (12 $\mu \mathrm{g}$ of a.i./seed), metalaxyl (3.2 $\mu \mathrm{g}$ of a.i./seed), ipconazole (4.0 $\mu \mathrm{g}$ of a.i./seed), and an insecticide, clothianidin $(81.0 \mu \mathrm{g}$ of a.i./seed); (ii) mefenoxam (11.7 $\mu \mathrm{g}$ of a.i./seed), fludioxonil (3.8 $\mu \mathrm{g}$ of a.i./seed), and the insecticide thiamethoxam (77.9 $\mu \mathrm{g}$ of a.i./seed); and (iii) pyraclostrobin (16.9 $\mu \mathrm{g}$ of a.i./seed), metalaxyl (13.2 $\mu \mathrm{g}$ of a.i./seed), fluxapyroxad (8.3 $\mu \mathrm{g}$ of a.i./seed), and the insecticide imidacloprid (127.0 $\mu \mathrm{g}$ of a.i./seed). These were the same treatments that were evaluated in the 2015 field experiments. Seed of the cultivar Kottman, which is susceptible to both Pythium spp. and some isolates of Phytophthora spp., was treated at Valent USA LLC Seed Protection Lab for this study. Nontreated seeds were surface sterilized in a $10 \%$ bleach solution for $1.5 \mathrm{~min}$, rinsed with deionized water for $1 \mathrm{~min}$, and allowed to dry thoroughly before use.

The seed plate assay was used to compare the efficacy of the three fungicide seed treatments and the relative pathogenicity of 49 isolates of Phytophthora, Pythium, and Phytopythium on the nontreated soybean seed (Table 3) as previously described by Broders et al. (2007). Briefly, mycelial plugs $5 \mathrm{~mm}$ in diameter were aseptically removed from the growing margins of a culture and transferred to the center of a $100-\mathrm{mm} 1.2 \%$ potato carrot agar plate. Isolates were placed in incubators to grow for 3 days at $20^{\circ} \mathrm{C}$ for Pythium and Phytopythium and 7 days at $25^{\circ} \mathrm{C}$ for Phytophthora. Ten seeds of one treatment were gently pushed into the agar, evenly spaced, approximately $1 \mathrm{~cm}$ from the edge of the plate. Plates were incubated in the dark for 7 days at $20^{\circ} \mathrm{C}$ or $25^{\circ} \mathrm{C}$ depending on the organism. From each plate, data for percentage germination of the seed and disease severity were collected. Seeds were considered germinated only if the radicle was $>1 \mathrm{~cm}$. A disease severity score was assigned as first described by Broders et al. (2007). Briefly, scores of 0 to 3 were assigned to the 10 seeds on each plate on the ordinal scale: $0=$ $100 \%$ germination with no infection, $1=70$ to $99 \%$ germination with lesions on the roots, $2=30$ to $69 \%$ germination with lesions on the roots, and $3=0$ to $29 \%$ germination with lesions on the roots (Fig. 1).

There were three replicate plates of each seed treatment-isolate combination, and the experiment was done twice, for a total of six replicate plates for each treatment-isolate combination. Subsets of the isolates were evaluated against the fungicide seed treatments over time in an incomplete block design for a total of 14 subsets with a range of 4 to 10 isolates in each. One isolate, Py. ultimum var. ultimum (Miami 137), was included in each subset to verify that the responses of the isolates were the same over time. Plates within a subset were randomized within the incubator. The seed rot score data from isolates that caused measurable seed rot (relative marginal effect score of $>0.30$ on the nontreated seed) were then combined for final analysis via a nonparametric relative marginal effects analysis as described by Shah and Madden (2004). Data were analyzed with PROC MIXED in SAS. Additionally, six Py. ultimum var. ultimum isolates were used to compare intraspecies variation in a separate nonparametric relative marginal effects analysis as described by Shah and Madden (2004) with PROC MIXED in order to identify variation within a species. Fungicide seed treatment, oomycete species, and their interaction were considered fixed effects, and the experiment subset and replicate were considered random effects. The slice option in SAS was used to determine whether there were any oomycete species by treatment interactions for each species included. The values shown in the seed plate assay result graphs depict the average seed rot scores for presentation purposes; statistics were based on the relative marginal effects.

\section{Results}

Each environment was considered to have disease pressure if seedlings with damping off (data not shown) were readily observed, as was a significant difference between the seed treatment fungicides 
and the nontreated control. Five of the eight field studies (NWARS2014, DEF-2015, NWARS-2016, SYN-2016, and VW-2016) all had significant differences in the V1/V2 plant populations for fungicide seed treatment (Table 4). For these environments that had significant difference for $\mathrm{V} 1 / \mathrm{V} 2$ plant populations, the precipitation that accumulated during the 14 dap was between 1.7 and $10.4 \mathrm{~cm}$ (Table 4). For four of the five environments, the yield differences were significantly different between the seed treatment fungicides (Table 4).

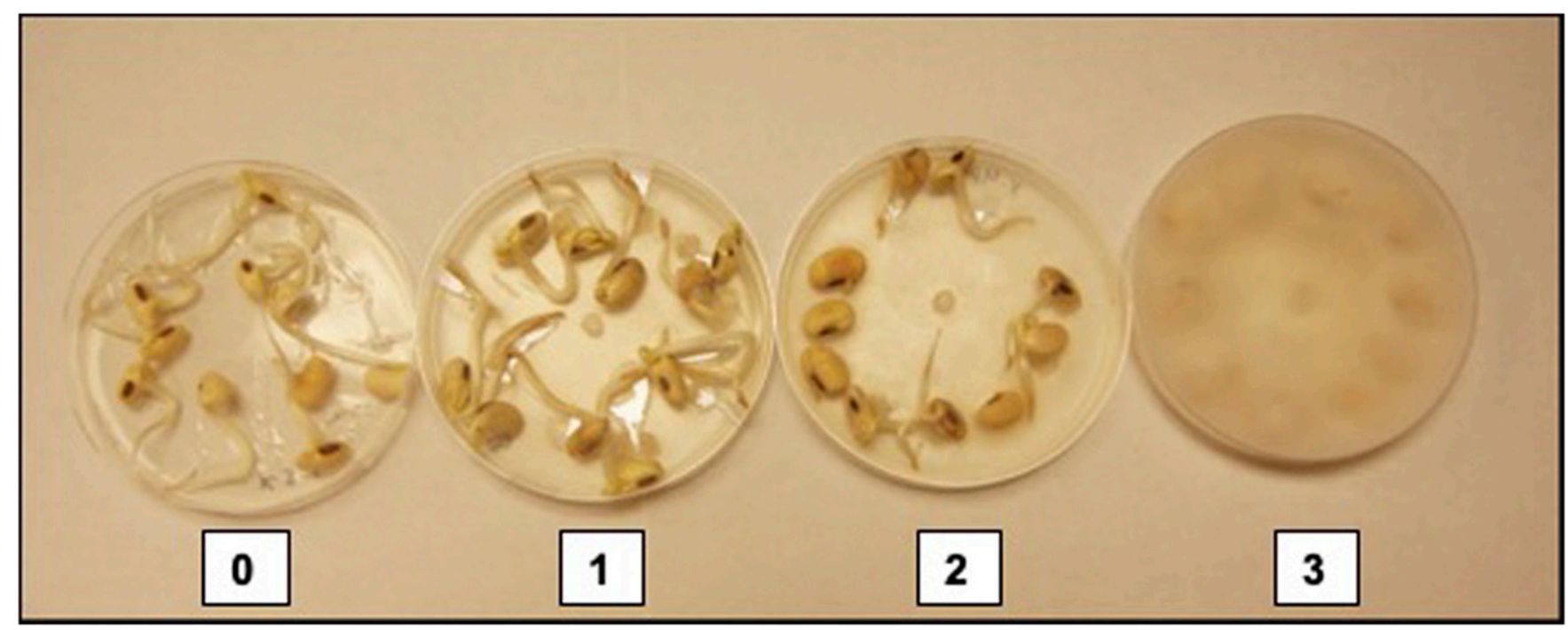

Fig. 1. Soybean seed rot scoring system used in a seed plate assay to evaluate the level of seed rot caused by different species of Phytophthora, Phytopythium, and Pythium and the effectiveness of fungicide seed treatments where $0=100 \%$ germination with no infection, $1=70$ to $99 \%$ germination with lesions on the roots, $2=30$ to $69 \%$ germination with lesions on the roots, and $3=0$ to $29 \%$ germination with lesions on the roots.

Table 4. Significance levels ( $P$ value) for the effects of fungicide $(\mathrm{F})$ seed treatments and nontreated on soybean stands at V1/V2, V3/V4, R/7R8, and yield $(\mathrm{kg} / \mathrm{ha})$ with different soybean cultivars ${ }^{\mathrm{z}}(\mathrm{C})$ in environments with varying disease pressure during 2014, 2015, and 2016. Degrees of freedom is abbreviated as df.

\begin{tabular}{|c|c|c|c|c|c|c|}
\hline \multirow[b]{2}{*}{ Environment } & \multirow[b]{2}{*}{ df } & \multicolumn{3}{|c|}{ Plant population } & \multirow[b]{2}{*}{ Yield } & \multirow[b]{2}{*}{ Precipitation 14 days after planting $(\mathrm{cm})$} \\
\hline & & V1/V2 & V3/V4 & $\mathbf{R 7 / R 8}$ & & \\
\hline VW-2014 & & & & & & 4.8 \\
\hline $\mathrm{C}$ & 1 & 0.6780 & - & 0.0370 & 0.1454 & \\
\hline $\mathrm{F}$ & 7 & 0.9442 & - & 0.7637 & 0.0408 & \\
\hline $\mathrm{C} \times \mathrm{F}$ & 7 & 0.5441 & - & 0.9515 & 0.9824 & \\
\hline NWARS-2014 & & & & & & 10.4 \\
\hline $\mathrm{C}$ & 1 & 0.0164 & 0.0181 & 0.0230 & 0.232 & \\
\hline $\mathrm{F}$ & 7 & $<0.0001$ & $<0.0001$ & $<0.0001$ & $<0.0001$ & \\
\hline $\mathrm{C} \times \mathrm{F}$ & 7 & 0.3150 & 0.2739 & 0.3204 & 0.3623 & \\
\hline DEF-2015 & & & & & & 8.2 \\
\hline $\mathrm{C}$ & 3 & $<0.0001$ & $<0.0001$ & 0.4290 & $<0.0001$ & \\
\hline $\mathrm{F}$ & 3 & $<0.0001$ & $<0.0001$ & 0.0141 & $<0.0001$ & \\
\hline $\mathrm{C} \times \mathrm{F}$ & 9 & 0.0169 & 0.0120 & 0.1985 & 0.0074 & \\
\hline NWARS-2015 & & & & & & 14.5 \\
\hline $\mathrm{C}$ & 2 & 0.5550 & 0.5897 & 0.4478 & 0.1745 & \\
\hline $\mathrm{F}$ & 3 & 0.8061 & 0.7532 & 0.6089 & 0.3440 & \\
\hline $\mathrm{C} \times \mathrm{F}$ & 6 & 0.0551 & 0.0451 & 0.0634 & 0.2930 & \\
\hline DEF-2016 & & & & & & 2.5 \\
\hline $\mathrm{C}$ & 6 & 0.4209 & 0.0154 & 0.0002 & $<0.0001$ & \\
\hline $\mathrm{F}$ & 1 & 0.0502 & $<0.0001$ & 0.0094 & 0.2234 & \\
\hline $\mathrm{C} \times \mathrm{F}$ & 6 & 0.3595 & 0.1145 & 0.3393 & 0.3586 & \\
\hline NWARS-2016 & & & & & & 8.2 \\
\hline $\mathrm{C}$ & 6 & 0.0268 & 0.0017 & 0.0014 & $<0.0001$ & \\
\hline $\mathrm{F}$ & 1 & 0.0001 & 0.0003 & 0.0006 & 0.0008 & \\
\hline $\mathrm{C} \times \mathrm{F}$ & 6 & 0.1759 & 0.1386 & 0.1590 & 0.2063 & \\
\hline SNY-2016 & & & & & & 1.7 \\
\hline $\mathrm{C}$ & 6 & 0.6334 & 0.5337 & 0.4993 & 0.0630 & \\
\hline $\mathrm{F}$ & 1 & 0.0138 & 0.0428 & 0.0813 & 0.0469 & \\
\hline $\mathrm{C} \times \mathrm{F}$ & 6 & 0.9092 & 0.8956 & 0.9643 & 0.7669 & \\
\hline VW-2016 & & & & & & 2.5 \\
\hline $\mathrm{C}$ & 6 & 0.1780 & 0.1682 & 0.4258 & $<0.0001$ & \\
\hline $\mathrm{F}$ & 1 & 0.0063 & 0.2909 & 0.3718 & 0.4395 & \\
\hline $\mathrm{C} \times \mathrm{F}$ & 6 & 0.3950 & 0.6601 & 0.8218 & 0.0833 & \\
\hline
\end{tabular}

z The cultivars in 2014 were Conrad (high partial resistance) and Sloan (moderately susceptible) to Phytophthora sojae and both susceptible to Pythium; in 2015, Conrad, Sloan, Kottman (Rpslk, Rps3a, high partial resistance to Ph. sojae, but susceptible to Pythium), and Lorain (Rpslc) and partial resistance to Pythium; and in 2016, Conrad, Sloan, Kottman, Lorain, Clermont, Dennison, and Streeter. 
Field evaluations 2014. Only one of the two environments (NWARS-2014) received sufficient precipitation to discriminate the efficacy between the seven fungicide seed treatments. In the NWARS-2014 environment, the cultivar-fungicide seed treatment interaction was not significant $(P>0.30)$ for early, late plant populations and yield, and the cultivars were different from each other $(P \leq$ 0.0164), with Sloan having lower plant populations than Conrad (Table 5). Seeds treated with either of the two combinations of metalaxyl (3.0 or $6.0 \mu \mathrm{g}$ of a.i./seed) and ethaboxam (12.0 $\mu \mathrm{g}$ of a.i./seed) had significantly greater plant populations at growth stages V1/V2 (Table 5) and V3/V4 (data not shown) as well as yield (Table 5) for the more susceptible cultivar, Sloan. In addition to these two seed treatments, mefenoxam alone at the higher rate $(23.0 \mu \mathrm{g}$ of a.i./seed $)$ had significantly greater stand than the nontreated check for the cultivar with higher level of resistance, Conrad. These three seed treatments and the combination of pyraclostrobin and metalaxyl had significantly greater yields than the nontreated based on LS means for Conrad (Table 5).

Field evaluations 2015. The NWARS-2015 environment received a combined total of $14.5 \mathrm{~cm}$ of water through irrigation $(4.0 \mathrm{~cm})$ and natural rainfall, including $7.5 \mathrm{~cm}$ that fell in a $48-\mathrm{h}$ period, and thus flooding and soil crusting had a greater impact on stand and yield and masked any effect of fungicide seed treatments or cultivars (Supplementary Fig. S1). At the DEF-2015 environment, there was a significant cultivar-fungicide seed treatment interaction and a highly significant difference between the four cultivars and four fungicide seed treatments for both V1/V2 plant population and yield. For the most susceptible cultivar, Sloan, seed treated with a combination of metalaxyl (3.2 $\mu \mathrm{g}$ of a.i./seed) plus ethaboxam (12.0 $\mu \mathrm{g}$ of a.i./seed) or metalaxyl (13.2 $\mu \mathrm{g}$ of a.i./seed) plus pyraclostrobin (16.9 $\mu \mathrm{g}$ of a.i./seed) had significantly greater plant populations and yield than seed that received mefenoxam (11.7 $\mu \mathrm{g}$ of a.i./seed $)$ alone (Table 6). However, the seed treated with metalaxyl (3.2 $\mu \mathrm{g}$ of a.i./seed) plus ethaboxam (12.0 $\mu$ g of a.i./seed) had greater yields than the two seed treatments and the nontreated control. The cultivars with higher levels of resistance toward Ph. sojae (Rps gene plus partial resistance [Kottman, Lorain]) were not significantly different between treated and nontreated seed for yield (Table 6).

Field evaluations 2016. These field studies focused on seven cultivars with and without seed treatment in four different environments. The fixed effect of environment was highly significantly different $(P<0.0001)$, as were the interactions between fungicide seed treatment and environment $(P<0.01)$ and cultivar and environment $(P \leq 0.03)$ for plant populations at all growth stages and for yield (Supplementary Table S2). Because of the high level of significance for environment and the interactions, each environment was evaluated separately. The seed treated with the mixture of ethaboxam (12.0 $\mu \mathrm{g}$ of a.i./seed) plus metalaxyl (3.2 $\mu \mathrm{g}$ of a.i./seed) plus clothianidin $(75.1 \mu \mathrm{g}$ of a.i./seed) plus ipconazole $(3.8 \mu \mathrm{g}$ of a.i./seed $)$ had significantly greater early stand at V1/V2 $(P \leq 0.01)$ when compared with the nontreated seed at three of four environments. Seed treatments affected yield at one environment $(P=0.0002)$ (Table 4$)$.

Table 5. Comparison of fungicide treatment combinations for the efficacy toward Phytophthora, Phytopythium, and Pythium compared with nontreated control on the soybean cultivar Sloan with moderate susceptibility and Conrad with high partial resistance to Phytophthora sojae, and both are moderately susceptible to several species of Pythium at one environment NWARS in 2014

\begin{tabular}{|c|c|c|c|c|}
\hline \multirow{2}{*}{$\begin{array}{l}\text { Fungicide seed treatment }{ }^{y} \text { (rate in } \mu \mathrm{g} \\
\text { of a.i./seed) }\end{array}$} & \multicolumn{2}{|c|}{ Plant population/hax ${ }^{x}$ /V2 } & \multicolumn{2}{|c|}{ Yield (kg/ha) } \\
\hline & Sloan $^{z}$ & Conrad & Sloan & Conrad \\
\hline Metalaxyl (6.2) & $71,758 \mathrm{f}$ & $169,349 \mathrm{~cd}$ & $1,074 \mathrm{fg}$ & $1,186 \mathrm{e}$ \\
\hline Metalaxyl (3.0) + ethaboxam (12.0) & 299,948 a & $322,910 \mathrm{a}$ & $2,275 \mathrm{ab}$ & $2,410 \mathrm{a}$ \\
\hline Metalaxyl (6.0) + ethaboxam (12.0) & $289,902 \mathrm{a}$ & $295,642 \mathrm{a}$ & $2,200 \mathrm{~b}$ & $2,462 \mathrm{a}$ \\
\hline Mefenoxam (11.7) & $68,888 \mathrm{f}$ & 166,478 cde & $776 \mathrm{~g}$ & 1,332 def \\
\hline Mefenoxam (23.0) & 134,905 cdef & $254,023 \mathrm{ab}$ & 1,114 efg & $1,995 \mathrm{abc}$ \\
\hline $\begin{array}{l}\text { Metalaxyl }(24.9)+\text { prothioconazole }(8.1)+ \\
\text { penflufen }(4.0)+\text { imidacloprid }(101.0)\end{array}$ & $126,294 \mathrm{cdef}$ & $179,395 \mathrm{bc}$ & 1,144 defg & 1,610 defg \\
\hline $\begin{array}{l}\text { Pyraclostrobin }(16.9)+\text { metalaxyl }(13.2)+ \\
\text { fluxapyroxad }(8.3)+\text { imidacloprid }(127.0)\end{array}$ & 152,127 cde & $196,616 \mathrm{bc}$ & $1,632 \mathrm{~cd}$ & $1,879 \mathrm{bc}$ \\
\hline Nontreated control & 87,545 ef & 96,155 def & $872 \mathrm{fg}$ & $1,034 \mathrm{fg}$ \\
\hline Overall mean & 153,920 & 209,386 & 1,386 & 1,738 \\
\hline Least significant difference $(P<0.05)$ & 66,329 & 94,507 & 358 & 633 \\
\hline
\end{tabular}

$\mathrm{x}$ Plant population data were collected at soybean growth state V1 to V2 when the first or second trifoliate was visible.

${ }^{\mathrm{y}}$ Fungicide formulations and trade names are listed in Table 2.

${ }^{\mathrm{z}}$ Least square means among treatments for both cultivars followed by the same letter are not significantly different based on Fisher's protected least significant difference at $P<0.05$.

Table 6. Comparison of three fungicide seed treatment combinations for the efficacy toward Phytophthora, Phytopythium, and Pythium compared with nontreated control on cultivars ${ }^{\mathrm{x}}$ Sloan, Conrad, Kottman, and Lorain in one environment (DEF-2015) in 2015

\begin{tabular}{|c|c|c|c|c|c|c|c|c|}
\hline \multirow[b]{2}{*}{ Fungicide rate ( $\mu \mathrm{g}$ of a.i./seed) } & \multicolumn{4}{|c|}{ Plant population ${ }^{\mathrm{y}}$ V1/V2 } & \multicolumn{4}{|c|}{ Yield (kg/H) } \\
\hline & Sloan & Conrad & Kottman & Lorain & Sloan & Conrad & Kottman & Lorain \\
\hline $\begin{array}{l}\text { Metalaxyl (3.2) + ethaboxam (12.0) + } \\
\text { ipconazole (4.0) + clothianidin }(81.0)\end{array}$ & $221,961 \mathrm{a}^{\mathrm{z}}$ & $253,926 \mathrm{a}$ & $281,581 \mathrm{a}$ & $293,433 \mathrm{a}$ & $1,382 \mathrm{a}$ & $1,214 \mathrm{a}$ & $1,559 \mathrm{ab}$ & $2,030 \mathrm{a}$ \\
\hline $\begin{array}{l}\text { Mefenoxam }(11.7)+\text { fludioxonil }(3.8)+ \\
\text { thiamethoxam }(77.9)\end{array}$ & $141,150 \mathrm{~b}$ & $183,890 \mathrm{~b}$ & 249,616 a & $286,250 \mathrm{a}$ & $901 \mathrm{bc}$ & $1,021 \mathrm{ab}$ & $1,346 \mathrm{~b}$ & $1,932 \mathrm{a}$ \\
\hline $\begin{array}{l}\text { Pyraclostrobin }(16.9)+\text { metalaxyl }(13.2)+ \\
\text { fluxapyroxad }(8.3)+\text { imidacloprid }(127.0)\end{array}$ & $211,904 \mathrm{a}$ & $194,665 \mathrm{ab}$ & $258,595 \mathrm{a}$ & $282,659 \mathrm{ab}$ & $1,066 \mathrm{~b}$ & $1,076 \mathrm{ab}$ & $1,635 \mathrm{a}$ & $1,952 \mathrm{a}$ \\
\hline Nontreated control & $107,389 \mathrm{~b}$ & $151,925 \mathrm{~b}$ & $211,545 \mathrm{~b}$ & $273,321 \mathrm{~b}$ & $740 \mathrm{c}$ & $953 \mathrm{~b}$ & $1,524 \mathrm{ab}$ & $1,882 \mathrm{a}$ \\
\hline Overall mean & 170,601 & 196,101 & 250,334 & 283,915 & 1,022 & 1,066 & 1,516 & 1,949 \\
\hline
\end{tabular}

$\mathrm{x}$ The cultivar Sloan (S) has moderate susceptibility and Conrad (C) has high partial resistance to Phytophthora sojae and both are moderately susceptible to several species of Pythium; Kottman (Rps 1 , Rps3a, high partial resistance to Ph. sojae and moderately susceptible to Pythium spp.) and Lorain (Rps 1 , high partial resistance to both $P h$. sojae and Pythium spp.).

y Plant population data were collected at soybean growth stage V1/V2, when the soybean plants' first or second trifoliate was visible.

${ }^{\mathrm{z}}$ Least square mean values followed by the same letter in a column are not significantly different. 
A

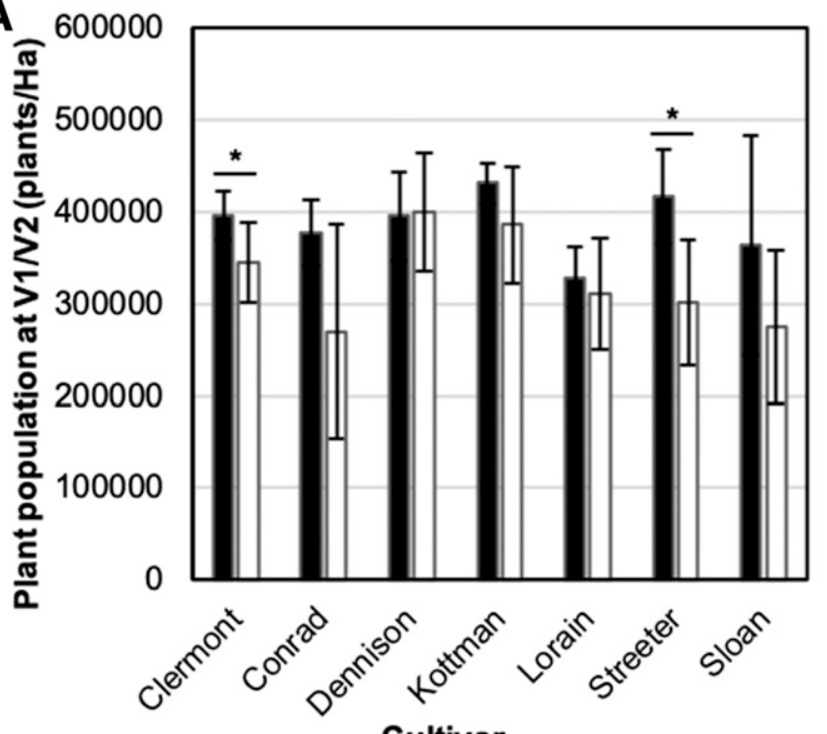

Cultivar

metalaxyl (3.2) + ethaboxam (12.0) + ipconazole (4.0) + clothianidin (81.0)

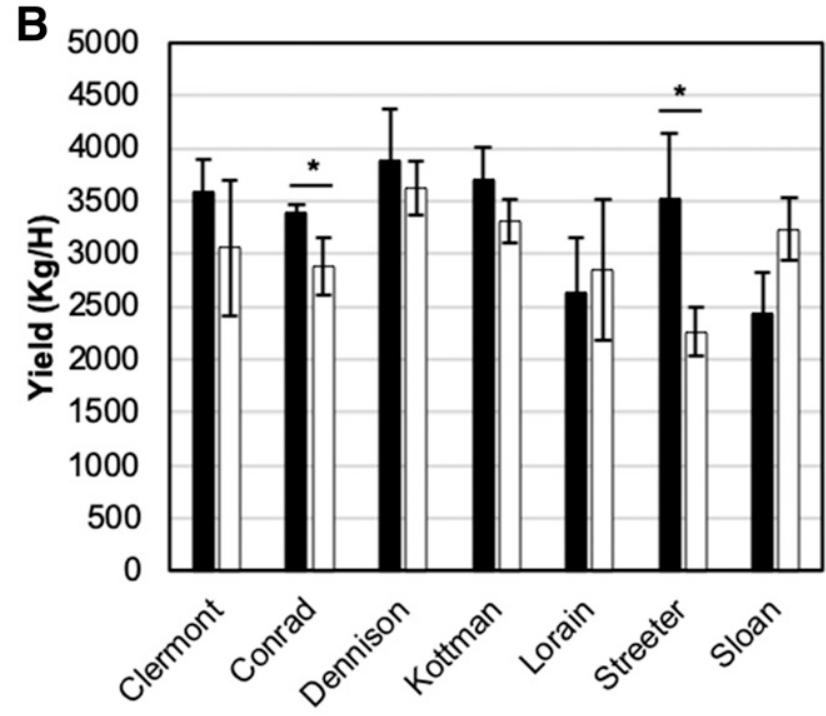

Cultivar

$\square$ Nontreated

Fig. 2. Comparison of seed treated with ethaboxam ( $12.0 \mu \mathrm{g}$ of a.i./seed) plus metalaxyl (3.2 $\mu \mathrm{g}$ of a.i./seed) compared with nontreated seed among seven soybean cultivars for $\mathbf{A}$, early plant population (V1/N2) and B, yield (kg/ha) in a field study at the NWARS-16 environment. An asterisk indicates that there was a significant difference $(P \leq 0.05)$ between the treated and nontreated seed for that cultivar.

Table 7. Comparison and significance of least squares estimates for early plant population and yield of the soybean seed of two cultivars Conrad and Sloan treated with the mixture of metalaxyl (3.2 $\mu \mathrm{g}$ of a.i./seed) plus ethaboxam $(12.0 \mu \mathrm{g}$ of a.i./seed) plus clothianidin $(75.1 \mu \mathrm{g}$ of a.i./seed) + ipconazole (3.8 $\mu \mathrm{g}$ of a.i./seed) in seven different environments in Ohio. Degrees of freedom is abbreviated as df.

\begin{tabular}{lccccccc}
\hline & Estimate & Standard error & df & $\boldsymbol{t}$ value & $\boldsymbol{P}$ value & Lower & Upper \\
\hline V1-V2 plant population & $-69,183$ & $7,041.17$ & 50.31 & -9.83 & $<0.0001$ & $-83,323$ & $-55,042$ \\
Yield & -371.92 & 49.44 & 56.02 & -7.52 & $<0.0001$ & -470.96 & -272.89 \\
\hline
\end{tabular}

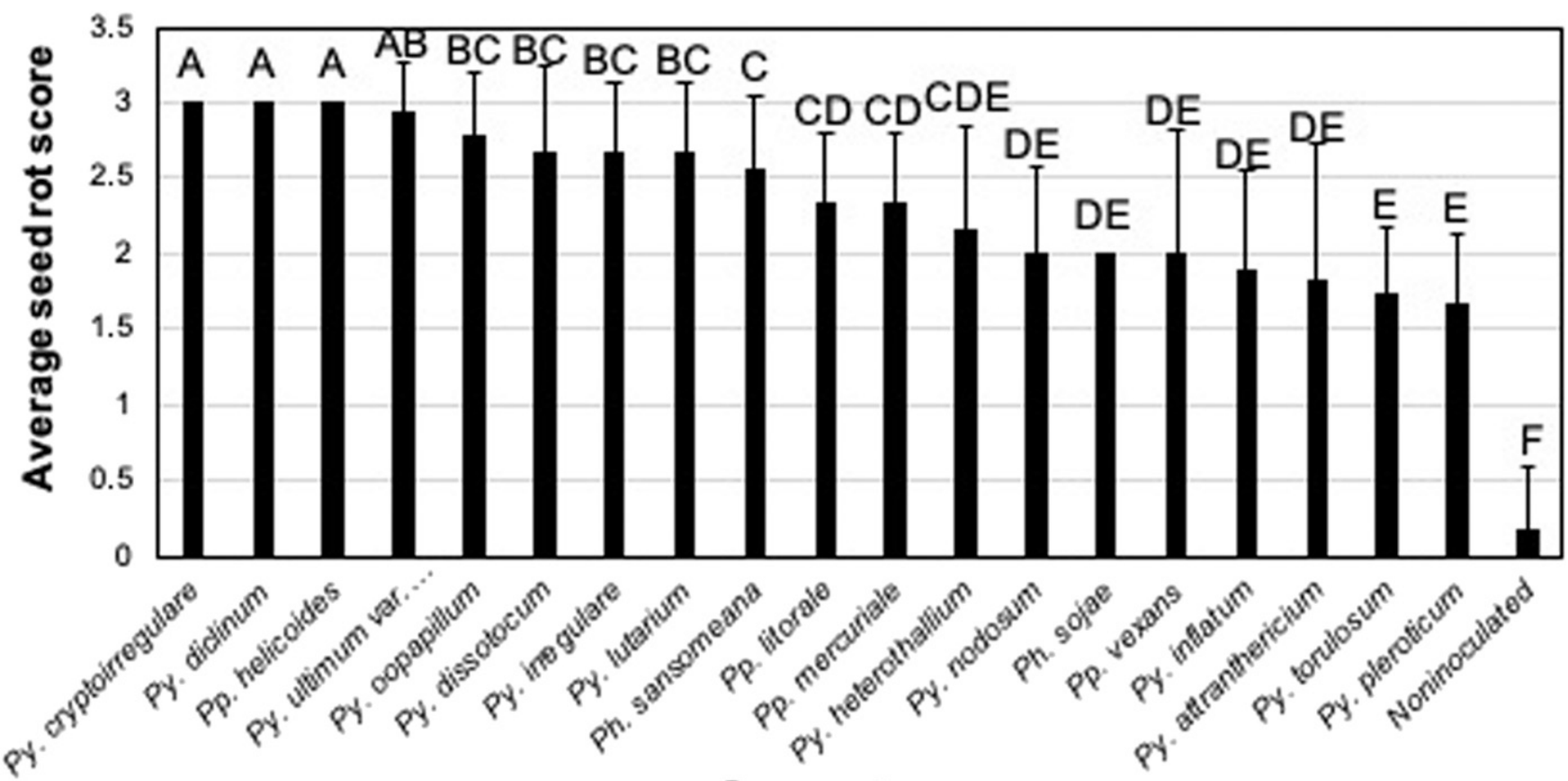

Oomycete spp.

Fig. 3. The average seed rot score of each Pythium (Py.), Phytophthora (Ph.), and Phytopythium (Pp.) species evaluated in a seed plate assay of nontreated seed of the cultivar Kottman. Bars sharing a letter are not significantly different from each other $(P \leq 0.05)$ based on relative marginal effects. Error bars are standard deviation. 
There was also a significant cultivar effect for early stand $(P=$ $0.0206)$ at V1/V2 at one environment, whereas yield was highly significant among cultivars $(P<0.0001)$ at two of the four environments. At the NWARS-2016 field environment the more susceptible cultivars with the seed treatment had greater stands and yields when compared with nontreated seed; there was no significant differences between the treatments and the nontreated seed for the more resistant cultivars (Fig. 2). For DEF-2016, the fungicide seed treatment significantly increased stand (V1/V2 and R7/R8) for the cultivar Streeter with high partial resistance to $P h$. sojae, as well as Sloan with moderate susceptibility. All these cultivars are susceptible to species of Pythium. Yields of the cultivars Clermont, Streeter, and Conrad were all significantly higher. The cultivar Sloan in the DEF-2015 environment had a lower stand than the initial population, indicating additional disease development throughout the season (data not shown), which can explain in part the lack of significance for yield. As in 2015, the seed treatment did not affect the yield of cultivars with higher levels of resistance to Ph. sojae (Clermont, Dennison, Kottman, and Lorain). The fungicide-treated seed for the cultivar Sloan also did not have greater yields, because of repeated losses during the season to Phytophthora root and stem rot.

The seed of cultivars Conrad and Sloan treated with the mixture of ethaboxam (12.0 $\mu \mathrm{g}$ a.i./seed) plus metalaxyl (3.2 $\mu \mathrm{g}$ of a.i./seed) plus clothianidin $(75.1 \mu \mathrm{g}$ of a.i./seed) plus ipconazole $(3.8 \mu \mathrm{g}$ of a.i./seed) were compared with the nontreated in seven environments. With environment as a fixed effect, the seed treated with fungicide mixture had higher plant populations and greater yields than the nontreated seed (Table 7).

Seed plate assay. Of the 49 isolates initially included in the experiments, five isolates did not cause seed rot and were not included in

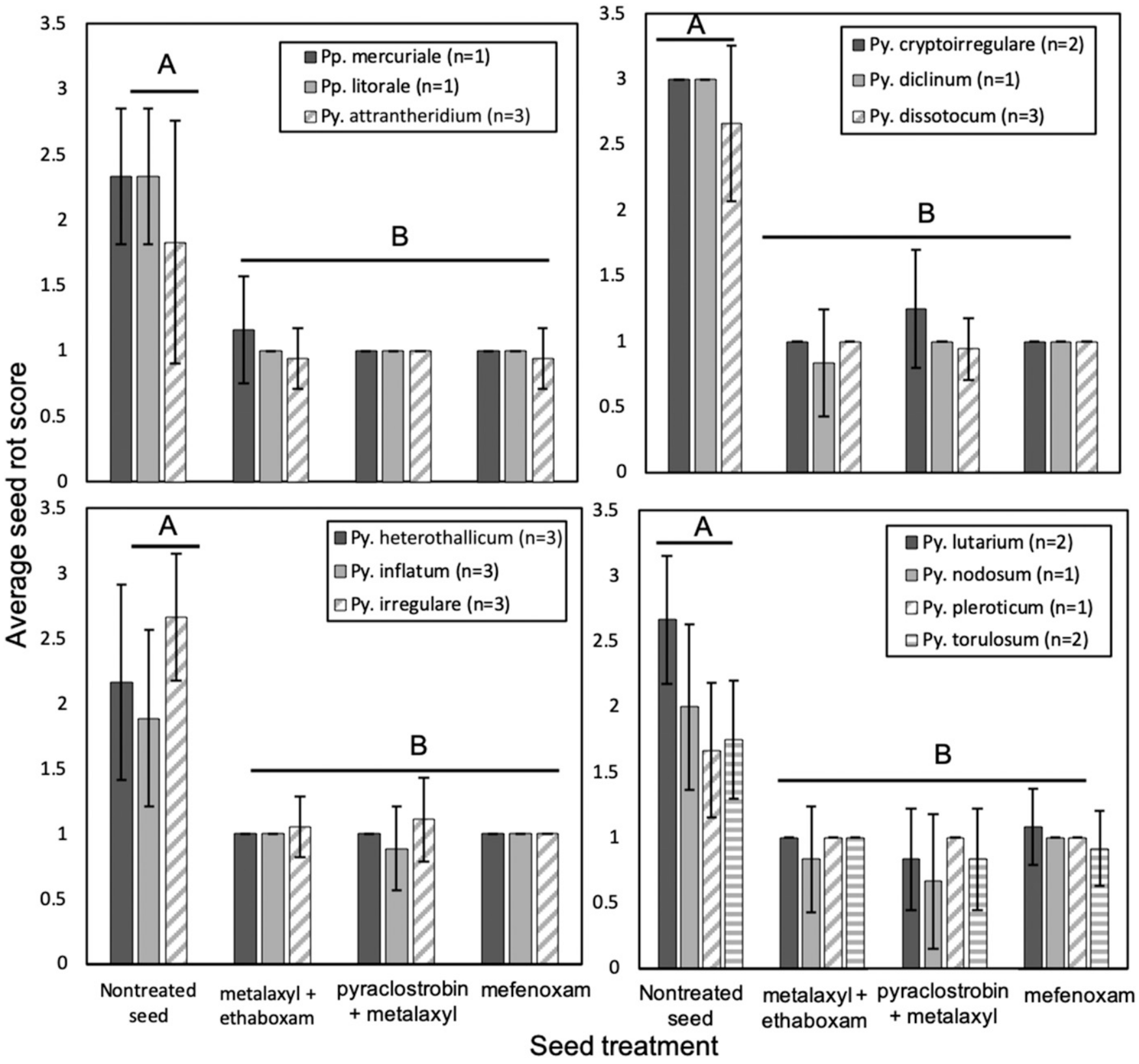

Fig. 4. The average seed rot score caused by 13 species of Pythium and Phytopythium on nontreated or fungicide-treated soybean seed ( $n=$ number of isolates per species) in a seed plate assay. Rates of each of the active ingredients for each mixture are as follows (in $\mu \mathrm{g}$ of a.i./seed): mefenoxam (11.7), fludioxonil (3.8) plus the insecticide thiamethoxam (77.0), metalaxyl (13.2) plus pyraclostrobin (16.9) plus fluxapyroxad (8.3) plus the insecticide imidacloprid (127.0), or ethaboxam (12.0) plus metalaxyl (3.2) plus ipconazole (4.0) and the insecticide clothianidin ( $81.0 \mu \mathrm{g}$ of a.i./seed). All data were grouped together and analyzed together, and no within-species differences were found in this group; data are separated into four graphs for visual clarity. Bars sharing a letter are not significantly different from one another $(P \leq 0.05)$ based on relative marginal effect. Standard deviation is shown. 
the pathogenicity or fungicide efficacy final analysis. The mean seed rot severity for the nontreated seed ranged from 1.7 to 3.0 , which is an indication of the relative aggressiveness for each isolate in this study (Fig. 3). There were 44 isolates with relative marginal effect scores of $>0.30$ on the nontreated seed. Pythium ultimum var. ultimum, Pythium diclinum, Pythium cryptoirregulare, and Phytopythium helicoides had the greatest seed rot scores on the nontreated Kottman seed. In this study, four isolates of $P$. sojae and Phytophthora sansomeana caused a low amount of seed rot, which was expected because of the Rps genes in Kottman (Rpslk and Rps3a; Dorrance et al. 2009).

Soybean seed treated with any of the three fungicide mixtures had significantly less $(P<0.05)$ seed rot when compared with the nontreated seed for 24 isolates of 13 different species of Pythium, Phytopythium (Fig. 4), and six isolates of two species of Phytophthora (Fig. 5). All three seed treatment mixtures limited seed infection of the Pythium spp. compared with the nontreated seed. However, there were differences in the level of efficacy between the seed treatments for isolates of the species Py. ultimum var. ultimum, Pythium oopapillum, Phytopythium vexans, and Pp. helicoides (Fig. 6). For an isolate of $P p$. helicoides, seed treated with mefenoxam (11.7 $\mu \mathrm{g}$ of a.i./ seed) had significantly greater seed rot scores than metalaxyl (13.2 $\mu \mathrm{g}$ of a.i./seed) plus pyraclostrobin (16.9 $\mu \mathrm{g}$ of a.i./seed) or ethaboxam $(12.0 \mu \mathrm{g}$ of a.i./seed) plus metalaxyl (3.2 $\mu \mathrm{g}$ of a.i./ seed) but significantly lower than the nontreated seed. Similarly, the mefenoxam (11.7 $\mu \mathrm{g}$ of a.i./seed) treatment reduced seed rot compared with the nontreated seed, but seed rot scores were greater

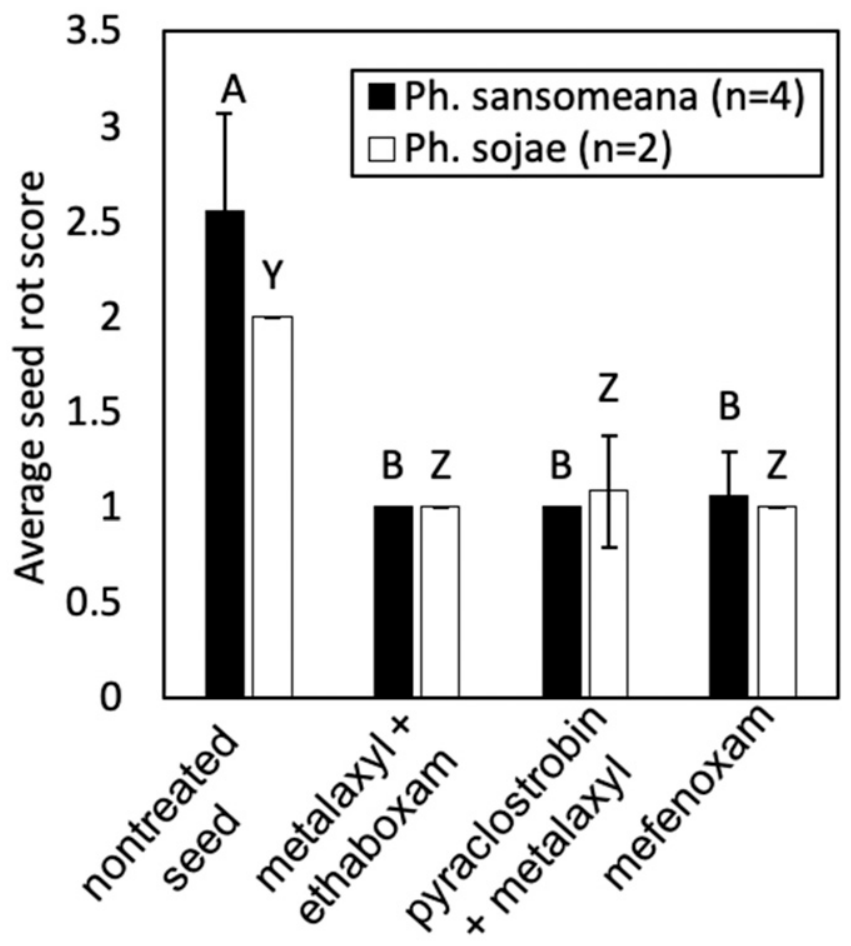

Seed treatment

Fig. 5. The average root rot score of soybean seed treated with one of three fungicide seed treatments and nontreated in a seed plate assay with four isolates of Phytophthora sojae and two isolates of Phytophthora sansomeana. Rates of each of the active ingredients for each mixture are as follows (in $\mu \mathrm{g}$ of a.i./seed): mefenoxam (11.7), fludioxonil (3.8) plus the insecticide thiamethoxam (77.0), metalaxyl (13.2) plus pyraclostrobin (16.9) plus fluxapyroxad (8.3) plus the insecticide imidacloprid (127.0), or ethaboxam (12.0) plus metalaxyl (3.2) plus ipconazole (4.0) and the insecticide clothianidin ( $81.0 \mu \mathrm{g}$ of a.i./seed). The isolates were analyzed together, and no within-species differences were found in this group; Phytophthora data are shown separately for visual clarity. Bars sharing a letter are not significantly different from one another $(P \leq 0.05)$ based on relative marginal effects. Error bars indicate the standard deviation. than the scores from seed treated with ethaboxam (12.0 $\mu \mathrm{g}$ of a.i./ seed) plus metalaxyl (3.2 $\mu \mathrm{g}$ of a.i./seed) for Py. ultimum var. ultimum (Fig. 6).

For a comparison between the response of the three fungicide seed treatment mixtures to six isolates of Py. ultimum var. ultimum, each with a similar level of aggressiveness, the fungicides reduced the level of seed rot compared with the nontreated for four of the isolates. Mefenoxam (11.7 $\mu \mathrm{g}$ of a.i./seed) was not significantly different from the nontreated for one isolate (N508.1) and had significantly greater seed rot scores compared with seed treated with ethaboxam (12.0 $\mu \mathrm{g}$ of a.i./seed) plus metalaxyl (3.2 $\mu \mathrm{g}$ of a.i./seed) for another (N201.2) (Fig. 7). These differences in response could be because of differences in sensitivity to mefenoxam, because some isolates within Ohio are insensitive (Broders et al. 2007; Dorrance et al. 2004).

\section{Discussion}

This study evaluated the efficacy of ethaboxam in combination with metalaxyl as a soybean seed treatment in Ohio fields with a history of seedling disease caused by multiple species of Pythium, Phytopythium, and Phytophthora and compared them with other seed treatment formulations in a seed plate assay. Our data indicate that ethaboxam used in combination with metalaxyl improved soybean stands across multiple environments and was effective in managing a number of species of Phytophthora, Phytopythium, and Pythium.

The fungicide ethaboxam was initially used in Korea to manage cucumber downy mildew, potato late blight, and pepper Phytophthora blight starting in the late 1990s (Kim et al. 1999, 2003). Ethaboxam was recently labeled for soybean seed treatment in the United States, and efficacy toward Ph. sojae and several species of Pythium in amended agar assays have been reported (Dorrance et al. 2012; Matthiesen et al. 2016, Radmer et al. 2017). Ethaboxam was also effective in managing metalaxyl-resistant $P$. ultimum var. ultimum on spring wheat, against Phytophthora capsici on pepper in the field and greenhouse (Matheron and Porchas 2015; White et al. 2019), and against Pseudoperonospora cubensis isolates that had reduced sensitivity to fluopicolide and propamocarb (Thomas et al. 2018). Earlier lab and greenhouse assays indicated that the combination of ethaboxam and metalaxyl as a fungicide seed treatment would provide protection from diverse Pythium spp. (Dorrance et al. 2012).

Environmental variation played a key part in the differences observed in the fungicide seed treatment effects across the individual environments in this and in other studies (Bradley 2008; Dorrance et al. 2009; Esker and Conley 2012). Specifically, the amount of rainfall in the 14 dap appears to affect the amount of disease pressure from Phytophthora, Phytopythium, and Pythium, as noted in previous field seed treatment studies (Bradley 2008; Dorrance et al. 2009). Esker and Conley (2012) did not find a difference for the efficacy of seed treatments in their study, but the rainfall 10 dap in the Wisconsin study ranged from 0.5 to $72.9 \mathrm{~mm}$, which was less than what occurred during our studies.

Seed treatment fungicide affected early plant populations in four of the five field environments that received $>2.5 \mathrm{~cm}$ of water 14 dap. Because the efficacy of fungicide seed treatments could be determined only with adequate disease pressure, efforts should be taken to properly irrigate research field sites to encourage pathogen development. However, overwatering or flooding may mask any effects by a fungicide or otherwise affect the study, as noted by others (Henshaw et al. 2007a, b; Kirkpatrick et al. 2006; VanToai et al. 1994). In this study, the effect of flooding overriding seed treatment effects occurred at three locations: NWARS-2015, with $14.5 \mathrm{~cm}$ of combined rainfall and irrigation 14 dap; and VW-2016 and DEF2016 , with nearly $48 \mathrm{~cm}$ of rainfall in total during the growing season. Despite these fields having a history of Pythium and Phytophthora infection, no significant fungicide effects on yield were found at these environments when excessive rainfall occurred.

The field sites in 2014 compared seed treatments containing ethaboxam and metalaxyl combinations with metalaxyl alone. When both active ingredients were present, stands were improved. Similarly, ethaboxam as part of a fungicide mixture improved stands 


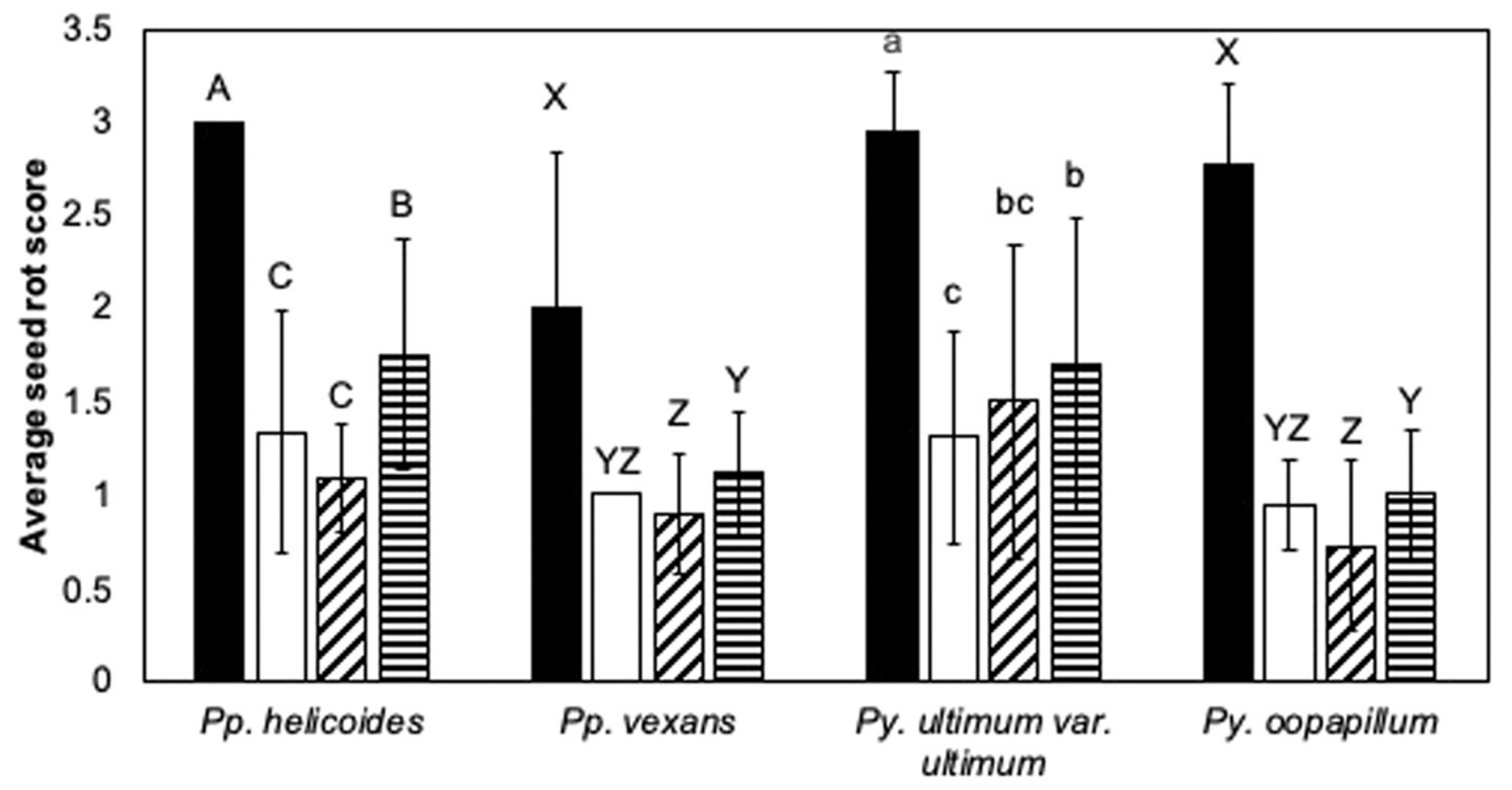

Omycete spp.

- Nontreated ametalaxyl + ethaboxam apyraclostrobin + metalaxyl amefenoxam

Fig. 6. Average seed rot scores of Phytopythium helicoides, Phytopythium vexans, Pythium ultimum var. ultimum, and Pythium oopapillum that exhibited a differential response in a seed plate assay to the fungicide seed treatments, with standard deviations shown. Rates of each of the active ingredients for each mixture are as follows (in $\mu \mathrm{g}$ of a.i./seed): mefenoxam (11.7), fludioxonil (3.8) plus the insecticide thiamethoxam (77.0), metalaxyl (13.2) plus pyraclostrobin (16.9) plus fluxapyroxad (8.3) plus the insecticide imidacloprid (127.0), or ethaboxam (12.0) plus metalaxyl (3.2) plus ipconazole (4.0) and the insecticide clothianidin (81.0 $\mu$ g of a.i./seed). Nontreated seed was used as a control. Bars with the same letter are not significantly different $(P \leq 0.05)$ based on relative marginal effects. Error bars represent standard deviation.

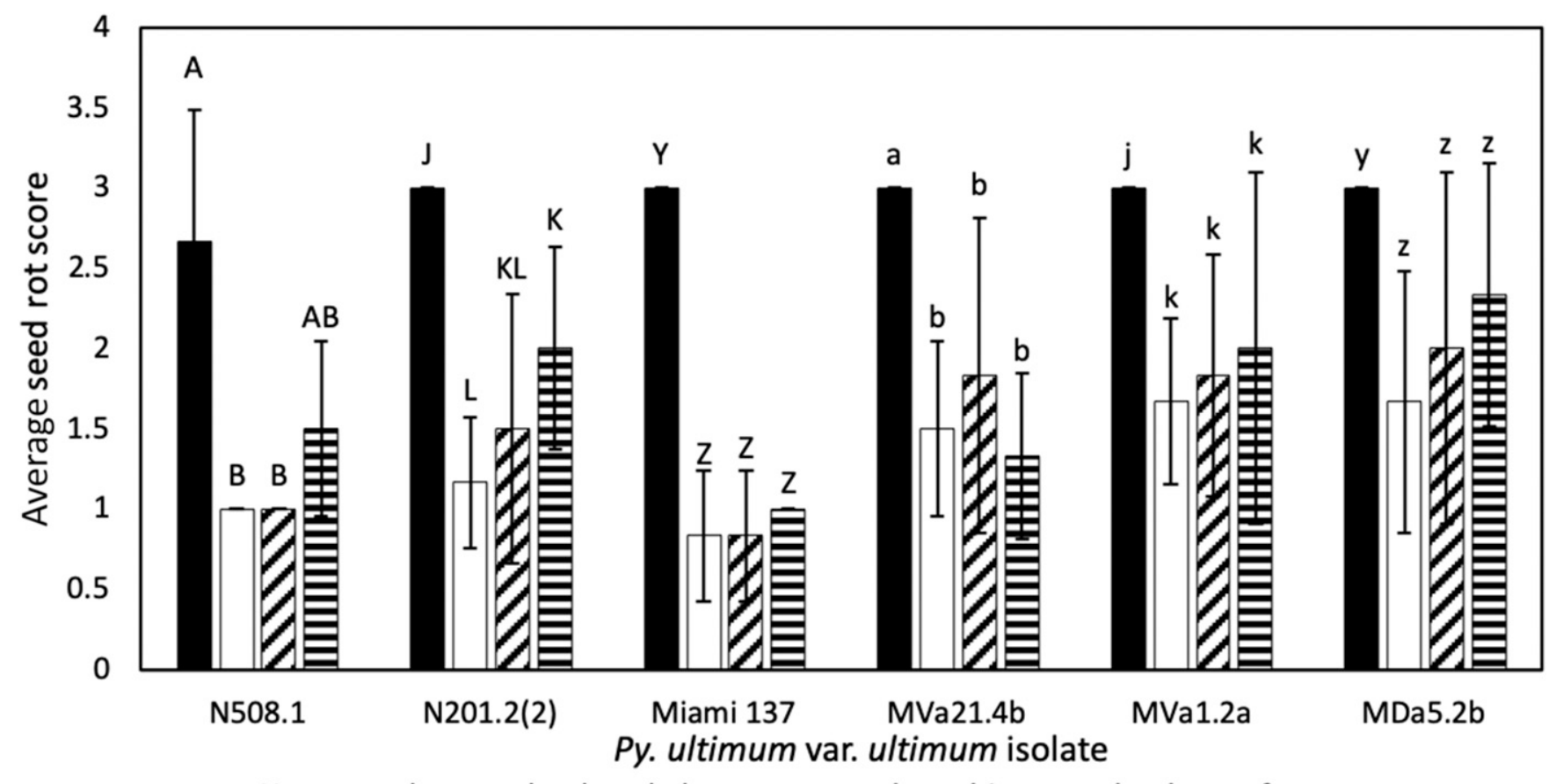

- Nontreated $\square$ metalaxyl + ethaboxam $\square$ pyraclostrobin + metalaxyl Emefenoxam

Fig. 7. Response of six Pythium ultimum var. ultimum isolates to three fungicide seed treatments and nontreated control used in the plate assay, with standard deviations shown. Within each isolate, the level of seed rot on the following seed treatments with the rates of each of the active ingredients for each mixture as follows (in $\mu \mathrm{g}$ of a.i./seed): mefenoxam (11.7), fludioxonil (3.8) plus the insecticide thiamethoxam (77.0), metalaxyl (13.2) plus pyraclostrobin (16.9) plus fluxapyroxad (8.3) plus the insecticide imidacloprid (127.0), or ethaboxam (12.0) plus metalaxyl (3.2) plus ipconazole (4.0) and the insecticide clothianidin (81.0 $\mu \mathrm{g}$ of a.i./seed). Bars with the same letter are not significantly different $(P \leq 0.05)$. Error bars represent standard deviation. 
and yield of spring wheat in northern Idaho, where metalaxylinsensitive strains of Pythium were reported (White et al. 2019). However, the metalaxyl treatment alone $(6.0 \mu \mathrm{g}$ of a.i./seed $)$ did not protect against seed and root disease for cultivars Conrad and Sloan. This finding is consistent with previous reports of low rates of metalaxyl having limited efficacy toward Ph. sojae (Dorrance and McClure 2001) and previous reports of the emergence of populations of Pythium with insensitivity to this fungicide in Ohio (Broders et al. 2007; Dorrance et al. 2004). Based on these studies, production of crops where metalaxyl-insensitive strains of Pythium are an issue, the addition of ethaboxam as a seed treatment component can limit losses.

At the DEF-2015 field site, there was a significant fungicidecultivar interaction; Conrad and Sloan both had greater yields from the fungicide seed treatments, whereas cultivars Lorain and Kottman did not. This difference in fungicide seed treatment effect may be because of the host resistance of Lorain (Rpslc, high partial to both Ph. sojae and some Pythium) and Kottman (Rps $1 k+R p s 3 a$, high partial to $P h$. sojae) performing better against the particular pathogen population in that environment. Interestingly, for three of the four 2016 environments plant populations were greater for the one fungicide seed treatment with ethaboxam plus metalaxyl, but yields were greater in only one environment for all but one cultivar (Lorain), which has a combination of resistance toward Ph. sojae and Pythium spp. In this highly favorable environment for seedling disease, the more susceptible cultivars performed better with the ethaboxam plus metalaxyl seed treatment when compared with the nontreated seed. Garnica and Giesler (2019) reported similar trends where this same seed treatment increased the number of soybean plants per hectare in several environments in Nebraska in 2017 and 2018. Soybeans have a great potential to compensate for reduced stands, and high standard deviations are very common in these types of studies.

The effect that resistance in a specific cultivar can have on the outcomes of these studies cannot be overstated. Cultivars with both Rps genes and partial resistance toward $P h$. sojae had the most consistent yield over many environments (Dorrance et al. 2003, 2009). When yields were averaged across years, with or without disease pressure, cultivar was a major factor for determining whether a seed treatment was cost effective in Wisconsin (Esker and Conley 2012). However, Esker and Conley (2012) emphasized that seed treatments are justified as insurance against loss because of the rapid changeover in soybean cultivars. This practice has been cost effective approximately $30 \%$ of the time in studies in North Dakota (Bradley 2008) and Wisconsin (Esker and Conley 2012). In this study for the highly susceptible cultivar Sloan, seed treatments were cost effective if measured by yield. The overall effects of these seed treatment fungicides were more readily measured on cultivars with greater susceptibility to species of Phytophthora, Phytopythium, or Pythium. Future field studies should include cultivars with a range of level of host resistance, taking care to include highly susceptible cultivars. This study is in agreement with others that suggest that soybean cultivar selection should be used in combination with fungicide seed treatment to protect against diseases caused by fungi and oomycete pathogen diseases (Dorrance et al. 2004, 2009; Esker and Conley 2012; Garnica and Giesler 2019; Kandel et al. 2016; Matthiesen et al. 2016; Marburger et al. 2014).

The seed plate assay was used to evaluate the efficacy of commercial fungicide combinations to a large number of Pythium spp. individually. This assay has been used previously to evaluate the relative pathogenicity of each oomycete species on nontreated seed (Broders et al. 2007) and to determine the effect of temperature on Pythium spp. aggressiveness (Matthiesen et al. 2016). In this study, there was a wide range of pathogenicity among the Phytophthora, Pythium, and Phytopythium isolates. Variation in the response to the seed treatments also was found between isolates of Py. ultimum var. ultimum. More importantly, this seed plate assay was also useful in identifying fungicide seed treatment-isolate interactions, which would be a great asset to companies as they explored new active ingredients or formulations.
Overall, our findings from the field environments support the findings from previous studies; fungicide seed treatments have stand- and yield-protecting benefits against species of Phytophthora, Phytopythium, and Pythium (Bradley 2008; Esker and Conley 2012; Garnica and Giesler 2019; Gaspar et al. 2014, 2017; Guy and Oplinger 1989; Guy et al. 1989; Poag et al. 2005; Urrea et al. 2013). Additionally, these results suggest that ethaboxam used in combination with metalaxyl was effective in managing a number of species of Phytophthora, Pythium, and Phytopythium commonly recovered from Ohio symptomatic soybean seedlings. Thus, this active ingredient could be a valuable tool for managing soybean seedling disease in Ohio and other regions where metalaxyl insensitivity is a concern.

\section{Acknowledgments}

A very special thank you and recognition for our farmer cooperators and for the research team at North West Agricultural Research Station for assistance with the field studies. We also thank Deloris Veney, Jonell Winger, Linda Weber, Amilcar Vargas, Katherine Wolfe, Whitney Welker, Frank Becker, Sarah Veney, Ella Hayward-Lara, Katie Kline, Sierra Cotrill, and Jack Waldock for technical assistance.

\section{Literature Cited}

Acharya, J., Bakker, M. G., Moorman, T. B., Kaspar, T. C., Lenssen, A. W., and Robertson, A. E. 2018. Effects of fungicide seed treatments and a winter cereal rye cover crop in no till on the seedling disease complex in corn. Can. J. Plant Pathol. 40:481-497.

Allen, T., Bradley, C., Sisson, A., Byamukama, E., Chilvers, M., Coker, C., Collins, A., Damicone, J., Dorrance, A., Dufault, N., Esker, P., Faske, T., Giesler, L., Grybauskas, A., Hershman, D., Hollier, C., Isakeit, T., Jardine, D., Kelly, H., Kemerait, R., Kleczewski, N., Koenning, S., Kurle, J., Malvick, D., Markell, S., Mehl, H., Mueller, D., Mulrooney, R., Nelson, B., Newman, M., Osborne, L., Overstreet, C., Padgett, G., Phipps, P., Price, P., Sikora, E., Smith, D., Spurlock, T., Tande, C., Tenuta, A., Wise, K., and Wrather, J. 2017. Soybean yield loss estimates due to diseases in the United States and Ontario, Canada, from 2010 to 2014. Plant Health Prog. 18:19-27.

Anderson, T. R., and Buzzell, R. I. 1982. Efficacy of metalaxyl in controlling Phytophthora root and stalk rot of soybean cultivars differing in field tolerance. Plant Dis. 66:1144-1145.

Balk, C. S. 2014. Assessment of resistance in soybean to Pythium ultimum and sensitivity of Ohio's diverse Pythium species towards metalaxyl. Thesis, the Ohio State University.

Bates, G. D., Rothrock, C. S., and Rupe, J. C. 2008. Resistance of the soybean cultivar Archer to Pythium damping-off and root rot caused by several Pythium spp. Plant Dis. 92:763-766.

Bradley, C. A. 2008. Effect of fungicide seed treatments on stand establishment, seedling disease, and yield of soybean in North Dakota. Plant Dis. 92: 120-125.

Bradley, C. A., Wax, L. M., Ebelhar, S. A., Bollero, G. A., and Pedersen, W. L. 2001. The effect of fungicide seed protectants, seeding rates, and reduced rates of herbicides on no-till soybean. Crop Prot. 20:615-622.

Broders, K. D., Lipps, P. E., Paul, P. A., and Dorrance, A. E. 2007 Characterization of Pythium spp. associated with corn and soybean seed and seedling disease in Ohio. Plant Dis. 91:727-735.

Broders, K. D., Wallhead, M. W., Austin, G. D., Lipps, P. E., Paul, P. A., Mullen, R. W., and Dorrance, A. E. 2009. Association of soil chemical and physical properties with Pythium species diversity, community composition, and disease incidence. Phytopathology 99:957-967.

Davidse, L. C., Hofman, A. E., and Velthuis, G. C. 1983. Specific interference of metalaxyl with endogenous RNA polymerase activity in isolated nuclei from Phytophthora megasperma f. sp. medicaginis. Exp. Mycol. 7:344-361.

Dorrance, A. E., Berry, S. A., Bowen, P., and Lipps, P. E. 2004. Characterization of Pythium spp. from three Ohio fields for pathogenicity on corn and soybean and metalaxyl sensitivity. Plant Health Prog. 2:1-7.

Dorrance, A. E., Ellis, M. L., McDuffee, D., and Arthur, K. 2012. Efficacy of ethaboxam toward species of Phytophthora and Pythium. Phytopathology. $102:$ S4.31.

Dorrance, A. E., Kurle, J., Robertson, A. E., Bradley, C. A., Giesler, L., Wise, K., and Concibido, V. C. 2016. Pathotype diversity of Phytophthora sojae in eleven states in the United States. Plant Dis. 100:1429-1437.

Dorrance, A. E., and McClure, S. A. 2001. Beneficial effects of fungicide seed treatments for soybean cultivars with partial resistance to Phytophthora sojae. Plant Dis. 85:1063-1068

Dorrance, A. E., McClure, S. A., and St. Martin, S. K. 2003. Effect of partial resistance on Phytophthora stem rot incidence and yield of soybean in Ohio. Plant Dis. 87:308-312.

Dorrance, A. E., Robertson, A. E., Cianzo, S., Giesler, L. J., Grau, C. R., Draper, M. A., Tenuta, A. U., and Anderson, T. R. 2009. Integrated management strategies for Phytophthora sojae combining host resistance and seed treatments. Plant Dis. 93:875-882. 
Ellis, M. L., McHale, L. K., Paul, P. A., St. Martin, S. K., and Dorrance, A. E. 2013. Soybean germplasm resistant to Pythium irregulare and molecular mapping of resistance quantitative trait loci derived from the soybean accession PI 424354. Crop Sci. 53:1008-1021.

Esker, P. D., and Conley, S. P. 2012. Probability of yield response and breaking even for soybean seed treatments. Crop Sci. 52:351-359.

Garnica, V. C., and Giesler, L. J. 2019. Soybean canopy coverage, population, and yield responses to seed treatment and cultivar resistance to Phytophthora sojae in Nebraska. Online Publication. Plant Health Prog. 20:229-237. doi: https:// doi.org/10.1094/PHP-05-19-0036-RS

Gaspar, A. P., Marburger, D. A., Mourtzinis, S., and Conley, S. P. 2014. Soybean seed yield response to multiple seed treatment components across diverse environments. Agron. J. 106:1955-1962.

Gaspar, A. P., Mitchell, P. D., and Conley, S. P. 2015. Economic risk and profitability of soybean fungicide and insecticide seed treatments at reduced seeding rates. Crop Sci. 55:924-933.

Gaspar, A. P., Mueller, D. S., Wise, K. A., Chilvers, M. I., Tenuta, A. U., and Conley, S. P. 2017. Response of broad-spectrum and target-specific seed treatments and seeding rate on soybean seed yield, profitability, and economic risk. Crop Sci. 57:2251-2262.

Gisi, U., Sierotzki, H., Cook, A., and McCaffery, A. 2002. Mechanisms influencing the evolution of resistance to Qo inhibitor fungicides. Pest Manag. Sci. 58:859-867.

Guy, S. O., and Oplinger, E. S. 1989. Soybean cultivar performance as influenced by tillage system and seed treatment. J. Prod. Agric. 2:57-62.

Guy, S. O., Oplinger, E. S., and Grau, C. R. 1989. Soybean cultivar response to metalaxyl applied in furrow and as a seed treatment. Agron. J. 81:529-532.

Henshaw, T. L., Gilbert, R. A., Scholberg, J. M. S., and Sinclair, T. R. 2007a. Soya bean (Glycine $\max$ L. Merr.) genotype response to early-season flooding: I. Root and nodule development. J. Agron. Crop Sci. 193:177-188.

Henshaw, T. L., Gilbert, R. A., Scholberg, J. M. S., and Sinclair, T. R. 2007b. Soya bean (Glycine max L. Merr.) genotype response to early-season flooding: II. Aboveground growth and biomass. J. Agron. Crop Sci. 193:189-197.

Ingram, D. M., and Cook, R. J. 1990. Pathogenicity of four Pythium species to wheat, barley, peas and lentils. Plant Pathol. 39:110-117.

Jiang, Y. N., Haudenshield, J. S., and Hartman, G. L. 2012. Characterization of Pythium spp. from soil samples in Illinois. Can. J. Plant Pathol. 34:448-454.

Kandel, Y. R., Wise, K. A., Bradley, C. A., Chilvers, M. I., Tenuta, A. U., and Mueller, D. S. 2016. Fungicide and cultivar effects on sudden death syndrome and yield of soybean. Plant Dis. 100:1339-1350.

Kim, B. S., Zhang, X. Z., Chung, E. K., Kim, D. S., Chun, S. J., and Park, W. B. 2003. Sensitivity of Phytophthora infestans isolates to fungicides metalaxyl and ethaboxam in Korea. Plant Pathology J. 19:143-147.

Kim, D. S., Chun, S. J., Jeon, J. J., Lee, S. W., and Joe, G. H. 2004. Synthesis and fungicidal activity of ethaboxam against oomycetes. Pest Manag. Sci. 60: 1007-1012.

Kim, D. S., Prak, H. C., Chun, S. J., Yu, S. H., Park, K. J., Oh, J. H., Shin, K. H., Koh, Y. J., Kim, B. S., Hahm, Y. I. and Chung, B. K. 1999. Field performance of a new fungicide ethaboxam against cucumber downy mildew, potato late blight and pepper Phytophthora blight in Korea. Plant Pathology J. 15:48-52.

Kirkpatrick, M. T., Rothrock, C. S., Rupe, J. C., and Gbur, E. E. 2006. The effect of Pythium ultimum and soil flooding on two soybean cultivars. Plant Dis. 90: 597-602.

Koenning, S. R., and Wrather, J. A. 2010. Suppression of soybean yield potential in the continental United States by plant diseases from 2006 to 2009. Plant Health Prog. https://doi.org/10.1094/PHP-2010-1122-01-RS

Littell, R. C., Milliken, G. A., Stroup, W. W., Wofinger, R. D., and Schabenberger, O. 2006. SAS System for Mixed Models. SAS Institute, Cary, NC.

Lueschen, W. E., Evans, S. D., Ford, J. H., Hoverstad, T. R., Kanne, B. K., Orf, J. H., Staricka, J. A., Stienstra, W. C., Warnes, D. D., and Hicks, D. R. 1991. Soybean production as affected by tillage in a corn and soybean management system: II. Seed treatment response. J. Prod. Agric. 4:580-585.

Marburger, D. A., Conley, S. P., Esker, P. D., Lauer, J. G., and Ané, J. M. 2014. Yield response to crop/genotype rotations and fungicide use to manage Fusarium-related diseases. Crop Sci. 55:889-898.

Marchand, G., Chen, Y., Berhane, N. A., Wei, L., Lévesque, C. A., and Xue, A. G. 2014. Identification of Pythium spp. from the rhizosphere of soybeans in Ontario, Canada. Can. J. Plant Pathol. 36:246-251.

Martin, F. N., and Loper, J. E. 1999. Soilborne plant diseases caused by Pythium spp.: Ecology, epidemiology, and prospects for biological control. Crit. Rev. Plant Sci. 18:111-181.

Matheron, M. E., and Porchas, M. 2015. Effectiveness of nine different fungicides for management of crown and root rot of chile pepper plants caused by Phytophthora capsici. Plant Health Prog. 16:218-222.

Matthiesen, R. L., Ahmad, A. A., and Robertson, A. E. 2016. Temperature affects aggressiveness and fungicide sensitivity of four Pythium spp. that cause soybean and corn damping off in Iowa. Plant Dis. 100:583-591.

Munkvold, G. P. 2009. Seed pathology progress in academia and industry. Annu. Rev. Phytopathol. 47:285-311.

Poag, P. S., Popp, M., Rupe, J., Dixon, B., Rothrock, C., and Boger, C. 2005. Economic evaluation of soybean fungicide seed treatments. Agron. J. 97: 1647-1657.
Radmer, L., Anderson, G., Malvick, D. M., Kurle, J. E., Rendahl, A., and Mallik, A. 2017. Pythium, Phytophthora, and Phytopythium spp. associated with soybean in Minnesota, their relative aggressiveness on soybean and corn, and their sensitivity to seed treatment fungicides. Plant Dis. 101:62-72.

Randall, E., Young, V., Sierotzki, H., Scalliet, G., Birch, P. R. J., Cooke, D. E. L., Csukai, M., and Whisson, S. C. 2014. Sequence diversity in the large subunit of RNA polymerase I contributes to mefenoxam insensitivity in Phytophthora infestans. Mol. Plant Pathol. 15:664-676.

Rizvi, S. S. A., and Yang, X. B. 1996. Fungi associated with soybean seedling disease in Iowa. Plant Dis. 80:57-60.

Rod, K. S., Walker, D. R., and Bradley, C. A. 2018. Evaluation of major ancestors of North American soybean cultivars for resistance to three Pythium species that cause seedling blight. Plant Dis. 102:2241-2252.

Rojas, J. A., Jacobs, J. L., Napieralski, S., Karaj, B., Bradley, C. A., Chase, T., Esker, P. D., Giesler, L. J., Jardine, D. J., Malvick, D. K., and Markell, S. G. 2017. Oomycete species associated with soybean seedlings in North America-Part I: Identification and pathogenicity characterization. Phytopathology 107:280-292.

Rosso, M. L., Rupe, J. C., Chen, P., and Mozzoni, L. A. 2008. Inheritance and genetic mapping of resistance to damping-off caused by in 'Archer' soybean. Crop Sci. 48:2215-2222.

Rupe, J. C., Rothrock, C. S., Bates, G., Rosso, M. L., Avanzato, M. V., and Chen, P. 2011. Resistance to Pythium seedling disease in soybean. Pages 261-276 in: Soybean: Molecular Aspects of Breeding, A. Sudaric, ed. InTech, Rijeka, Croatia. doi:10.5772/15301.

Schroeder, K. L., Martin, F. N., de Cock, A. W. A. M., Lévesque, C. A., Spies, C. F. J., Okubara, P. A., and Paulitz, T. C. 2013. Molecular detection and quantification of Pythium species: Evolving taxonomy, new tools, and challenges. Plant Dis. 97:4-20.

Scott, K., Balk, C., Veney, D., McHale, L. K., and Dorrance, A. E. 2019 Quantitative disease resistance loci towards Phytophthora sojae and three species of Pythium in six soybean nested association mapping populations. Crop Sci. 59:605-623.

Scott, K., Vargas, A., Eyre, M., and Dorrance, A. 2016. Efficacy of three soybean fungicide seed treatments against Pythium species in seed plate and growth chamber assays. Phytopathology. 106:S4:68.

Serrano, M., McDuffee, D., and Robertson, A. E. 2018. Damping-off caused by Pythium sylvaticum on soybeans subjected to periods of cold stress is reduced by seed treatments. Can. J. Plant Pathol. 40:571-579.

Shah, D. A., and Madden, L. V. 2004. Nonparametric analysis of ordinal data in designed factorial experiments. Phytopathology 94:33-43.

Taylor, R. J., Salas, B., Secor, G. A., Rivera, V., and Gudmestad, N. C. 2002 Sensitivity of North American isolates of Phytophthora erythroseptica and Pythium ultimum to mefenoxam (metalaxyl). Plant Dis. 86:797-802.

Thomas, A., Neufeld, K. N., Seebold, K. W., Braun, C. A., Schwarz, M. R., and Ojiambo, P. S. 2018. Resistance to fluopicolide and propamocarb and baseline sensitivity to ethaboxam among isolates of Pseudoperonospora cubensis from the Eastern United States. Plant Dis. 102:1619-1626.

Uchida, M., Roberson, R. W., Chun, S. J., and Kim, D. S. 2005. In vivo effects of the fungicide ethaboxam on microtubule integrity in Phytophthora infestans. Pest Manag. Sci. 61:787-792.

Urrea, K., Rupe, J., Chen, P., and Rothrock, C. S. 2017. Characterization of seed rot resistance to Pythium aphanidermatum in soybean. Crop Sci. 57:1394-1403.

Urrea, K., Rupe, J. C., and Rothrock, C. S. 2013. Effect of fungicide seed treatments, cultivars, and soils on soybean stand establishment. Plant Dis. 97: 807-812.

van der Plaats-Niterink, A. J. 1981. Monograph of the Genus Pythium. Studies in Mycology. Centraalbureau voor Schimmelculture, Baarn, Netherlands.

VanToai, T. T., Beuerlein, A. F., Schmitthenner, S. K., and St. Martin, S. K. 1994 Genetic variability for flooding tolerance in soybeans. Crop Sci. 34:1112-1115.

Vargas Loyo, A. J. 2018. Management of seedling diseases caused by Oomycetes, Phytophthora spp., Phytopythium spp. and Pythium spp. using seed treatment in Ohio. M.S. thesis, The Ohio State University.

Waterhouse, G. M. 1967. Key to Pythium Pringsheim. Mycol. Pap. 109:1-15.

Wei, L., Xue, A., Cober, E., Babcock, C., Zhang, J., Zhang, S., Li, W., Wu, J., and Liu, L. 2010. Pathogenicity of Pythium species causing seed rot and dampingoff in soybean under controlled conditions. Phytoprotection 91:3-10.

White, D. J., Chen, W., and Schroeder, K. L. 2019. Assessing the contribution of ethaboxam in seed treatment cocktails for the management of metalaxylresistant Pythium ultimum var ultimum in Pacific Northwest spring wheat production. Crop Prot. 115:7-12.

White, T. J., Bruns, T., Lee, S., and Taylor, J. 1990. Amplification and direct sequencing of fungal ribosomal RNA genes for phylogenetics. Pages 315-322 in: PCR Protocols: A Guide to Methods and Applications, M. A Innis, D. H. Gelfand, J. J. Sninsky, and T. J. White, eds. Academic Press, Cambridge, MA

Workneh, F., Yang, X. B., and Tylka, G. L. 1998. Effect of tillage practices on vertical distribution of Phytophthora sojae. Plant Dis. 82:1258-1263.

Zelaya-Molina, L. X., Ortega, M. A., and Dorrance, A. E. 2011. Easy and efficient protocol for oomycete DNA extraction suitable for population genetic analysis. Biotechnol. Lett. 33:715-720.

Zitnick-Anderson, K. K., and Nelson, B. D. 2015. Identification and pathogenicity of Pythium on soybean in North Dakota. Plant Dis. 99:31-38. 